\title{
Epidermal cell death in frogs with chytridiomycosis
}

\author{
Laura A Brannelly ${ }^{\text {Corresp., }}{ }^{1}$, Alexandra A Roberts ${ }^{1}$, Lee F Skerratt ${ }^{1,2}$, Lee Berger ${ }^{1,2}$ \\ 1 College of Public Health, Medical and Vet Sciences, James Cook University, Townsville, QLD, Australia \\ 2 Faculty of Veterinary and Agricultural Sciences, University of Melbourne, Melbourne, Victoria, Australia \\ Corresponding Author: Laura A Brannelly \\ Email address: laura.brannelly@pitt.edu
}

Background. Amphibians are declining at an alarming rate and one of the major causes of decline is the infectious disease chytridiomycosis. Parasitic fungal sporangia occur within epidermal cells causing epidermal disruption, but these changes have not been well characterised. Apoptosis (planned cell death) can be a damaging response to the host but may alternatively be a mechanism of pathogen removal for some intracellular infections.

Methods. In this study we experimentally infected two endangered amphibian species Pseudophryne corroboree and Litoria verreauxii alpina with the causal agent of chytridiomycosis and quantified cell death in the epidermis through two assays: terminal transferase-mediated dUTP nick end-labelling (TUNEL) and caspase 3/7.

Results. Cell death was positively associated with infection load, and morbidity of clinically infected animals. In infected amphibians, TUNEL positive cells were concentrated in epidermal layers, correlating to the localisation of infection within the skin. Caspase activity was stable and low in early infection, where pathogen loads were light but increasing. In animals that recovered from infection, caspase activity gradually increased as the infection cleared. Whereas, in amphibians that did not recover, caspase activity increased dramatically when infection loads peaked.

Discussion. Increased cell death may be a pathology of the fungal parasite, likely contributing to loss of skin homeostatic functions, but it is also possible that apoptosis suppression may be used initially by the pathogen to help establish infection. Further research should explore the specific mechanisms of cell death and more specifically apoptosis regulation during fungal infection. 
1 Epidermal cell death in frogs with chytridiomycosis

2 Laura A. Brannelly*1, Alexandra A. Roberts ${ }^{1}$, Lee F. Skerratt ${ }^{1,2}$, Lee Berger ${ }^{1,2}$

3

$4{ }^{1}$ One Health Research Group, College of Public Health, Medical and Veterinary Sciences. James

5 Cook University, Townsville, Queensland, Australia

$6 \quad{ }^{2}$ Faculty of Veterinary and Agricultural Sciences, University of Melbourne, Werribee, Victoria,

7 Australia

8

9 Running Head: Apoptosis in frogs with chytridiomycosis

10

11 *Address correspondence to Laura A. Brannelly, laura.brannelly@my.jcu.edu.au 
12 Abstract.

13 Background. Amphibians are declining at an alarming rate and one of the major causes of

14 decline is the infectious disease chytridiomycosis. Parasitic fungal sporangia occur within

15 epidermal cells causing epidermal disruption, but these changes have not been well

16 characterised. Apoptosis (planned cell death) can be a damaging response to the host but may

17 alternatively be a mechanism of pathogen removal for some intracellular infections.

18 Methods. In this study we experimentally infected two endangered amphibian species

19 Pseudophryne corroboree and Litoria verreauxii alpina with the causal agent of

20 chytridiomycosis and quantified cell death in the epidermis through two assays: terminal

21 transferase-mediated dUTP nick end-labelling (TUNEL) and caspase 3/7.

22 Results. Cell death was positively associated with infection load, and morbidity of clinically

23 infected animals. In infected amphibians, TUNEL positive cells were concentrated in epidermal

24 layers, correlating to the localisation of infection within the skin. Caspase activity was stable and

25 low in early infection, where pathogen loads were light but increasing. In animals that recovered

26 from infection, caspase activity gradually increased as the infection cleared. Whereas, in

27 amphibians that did not recover, caspase activity increased dramatically when infection loads

28 peaked.

29 Discussion. Increased cell death may be a pathology of the fungal parasite, likely contributing to

30 loss of skin homeostatic functions, but it is also possible that apoptosis suppression may be used

31 initially by the pathogen to help establish infection. Further research should explore the specific

32 mechanisms of cell death and more specifically apoptosis regulation during fungal infection. 


\section{1. Introduction.}

34 Amphibians globally are experiencing the greatest loss in biodiversity of all vertebrate taxa

35 (Stuart et al., 2004). One of the major causes of decline is disease, specifically a fungal parasite, 36 Batrachochytrium dendrobatidis, Bd (Skerratt et al., 2007), which causes the fatal skin disease

37 chytridiomycosis. So far, solutions for minimising $B d$ related mortality are lacking and research

38 devoted to improving survival rates within these declining populations will be key to

39 conservation management.

Although chytridiomycosis is a superficial epidermal infection, disruption to skin

41 function causes severe loss of electrolytes leading to cardiac failure (Voyles et al., 2009). Global

42 research into the host-parasite dynamics has shown that resistance varies among species,

43 populations and individuals. After demonstrating that vaccination is unlikely to be effective at

44 substantially reducing mortality (Cashins et al., 2013; McMahon et al., 2014), the focus has been

45 on identifying key immune factors that may then be selected for in breeding programs (Scheele

46 et al., 2014; Skerratt et al., 2016). While various potential immune mechanisms - such as

47 antimicrobial peptides (Woodhams et al., 2006a,b), cutaneous bacterial flora (Woodhams et al.,

48 2007), immune cell receptors (Savage \& Zamudio, 2011; Bataille et al., 2015) and lymphocyte

49 activity (Fites et al., 2014) - are currently being studied, few studies have explored cell death and

50 apoptosis in the skin as an immune mechanism.

51 Apoptosis is a controlled process resulting in programmed non-inflammatory cell death

52 via the action of caspase proteases and phagocytosis (Fink \& Cookson, 2005). It is vital to tissue

53 growth and differentiation and is associated with elimination of damaged cells and infectious

54 agents, particularly intracellular pathogens (Kim et al., 1998; Barber, 2001; Nogueira et al.,

55 2009; Lamkanfi \& Dixit, 2010; Ashida et al., 2011). Hosts utilise apoptosis of infected cells to 
56 block replication of pathogens, resulting in clearance of the infection. However, some pathogens

57 can evade the immune system by hijacking the host's apoptotic machinery: they produce

58 apoptosis inhibitors in order to aid in replication and survival, while others can induce apoptosis

59 to facilitate dissemination or destroy host immune cells (Weinrauch \& Zychlinsky, 1999;

60 Hasnain et al., 2003; Faherty \& Maurelli, 2008; Hacker, 2009; Lamkanfi \& Dixit, 2010).

61 Therefore, the ability of the host and pathogen to control apoptosis can greatly influence disease

62 severity and clinical outcomes.

Apoptosis, and more broadly general cell death, may be a pathology of $B d$ infection in

64

65

66

67

amphibians, as characteristic epidermal degenerative changes have been observed in $B d$-infected frogs by electron microscopy (Berger et al., 2005; Pasmans et al., 2010). Dissociation of epidermal intracellular junctions triggering detachment-induced apoptosis was observed when skin explants were treated with zoospore supernatants in vitro (Brutyn et al., 2012).

Transcriptomic studies have shown apoptosis pathways are upregulated in skin of resistant and susceptible frog species (Ellison et al., 2014). Amphibian splenocytes also undergo apoptosis when treated with $B d$ sporangial (but not zoospore) supernatants in in vitro assays, associated with increased intrinsic, extrinsic and effector caspase activity in these immune cells (Fites et al., 2013). Despite the evidence to suggest that $B d$ can induce apoptosis of specific cells in vitro, there are no studies that use direct and quantifiable assays, or that explore apoptosis mechanisms during progress of an infection in vivo. Furthermore, it is not known whether the host can effectively use apoptosis as an immune defence against chytridiomycosis.

The aim of this study was to quantify levels of cell death and apoptosis in amphibian skin during experimental infection of two species threatened by chytridiomycosis, the alpine tree frog, Litoria verreauxii alpina, and the southern corroboree frog, Pseudophryne corroboree. To ensure 
79 accurate measurement of the apoptotic effect, two methods of detection were utilised (Galluzzi et

80 al., 2009): caspase 3/7 protein assay, and terminal transferase-mediated dUTP nick end-labeling

81 (TUNEL) in situ assay. The caspase 3/7 assay quantifies the activity of effector caspases

82 activated by both the intrinsic and extrinsic apoptosis pathways, while the TUNEL assay detects

83 DNA fragmentation characteristically caused by cell death such as apoptosis, necrosis and

84 pyroptosis (Kelly et al., 2003). This exploratory project characterised measures of cell death and

85 apoptosis in epidermal cells. We tested the hypothesis that cell death and apoptosis was

86 correlated with infection intensity and host survival in order to explore if cell death is a

87 mechanism of disease resistance or cutaneous pathology. If infection load is positively correlated

88 with cell death, this could reflect either an effective immune response or pathology of disease. If

89 a high level of cell death is a pathology of disease we expect that high cell death to be present on

90 animals that succumb to disease. But if apoptosis was a useful immune response, we predict that

91 animals that cleared infection would have higher rates initially or at the time of Bd reductions.

92

93 2. Materials and Methods.

942.1 Study organisms

Litoria verreauxii alpina that were excess to a reintroduction trial (a total of 300 from two different populations) were obtained from Taronga Zoo, Sydney, and were part of a larger

97 experiment (Brannelly et al., 2016a, 2016b). Litoria $v$. alpina are a declining anuran endemic to

98 the Australian Alps in New South Wales and Victoria, Australia. The species is highly

99 susceptible to $B d$, which is the primary cause of decline (Bataille et al., 2015; Brannelly et al.,

100 2015b,2016). The animals sexually mature at 2 years and these animals ranged from two to three

101 years old and were captive raised under strict quarantine protocols and had never been exposed 
102 to $B d$. Animals were housed individually in $300 \times 195 \times 205 \mathrm{~mm}$ terrarium with gravel substrate,

103 at a room temperature of $18-20^{\circ} \mathrm{C}$. They were fed ad libitum three times weekly with juvenile

$104(10 \mathrm{~mm})$ crickets (Acheta domestica) (dusted with amphibian vitamins and gut-loaded). Animals

105 were misted twice daily for 60 seconds with reverse osmosis water. Temperature and humidity

106 were monitored daily.

107 Pseudophryne corroboree were excess to a breeding program at the Amphibian Research

108 Centre, Pearcedale, Victoria, Australia (a total of 120 adult animals from five different

109 populations). These animals were 5-8 years old and part of a larger research experiment

110 (Brannelly et al., 2016a, 2016b). Pseudophryne corroboree are functionally extinct in the wild,

111 and highly susceptible to $B d$ (Brannelly et al., 2015a; Brannelly, Skerratt \& Berger, 2015). These

112 animals were housed in the same conditions as above but on a paper towel substrate that was

113 changed once a fortnight.

\subsection{Inoculation}

116 Animals were allowed to acclimate to their new environment for at least seven days. All

117 animals were tested for $B d$ infection prior to the start of the experiment (see methods below) and

118 all were found to be negative. Cultures of $B d$ were harvested from tryptone, gelatin hydrolysate,

119 lactose (TGhL) agar plates after incubation at $23^{\circ} \mathrm{C}$ for 5 days. Three millilitres of artificial

120 spring water was poured onto the plates and incubated for 10 minutes to allow zoospores to be

121 released from zoosporangia to create the inoculum. Inoculum was poured off the plates and

122 zoospores were counted using a hemocytometer and then diluted with artificial spring water to

123 achieve the appropriate concentration as described below. Samples sizes for each inoculation

124 found in Table 1. Note that the inoculation strain used for obtaining infected samples for the 
125 TUNEL assay in L. v. alpina differs from the others, and was used to obtain higher infection

126 rates.

127

128 2.2.1 TUNEL Assay

129 Litoria $v$. alpina used in the TUNEL assay, were inoculated with a New South Wales strain of

$130 B d$ (WastePoint-L.v.alpina-2013-LB2, Passage number 1). Animals were inoculated with 5x105

131 zoospores in $10 \mathrm{~mL}$ of inoculum and held in inoculation containers for $24 \mathrm{~h}$.

132 Pseudophryne corroboree were inoculated with a New South Wales strain of $B d$

133 (AbercrombieR-L.booroologensis-2009-LB1, Passage number 11). Animals were inoculated

134 with $1 \times 10^{6}$ zoospores by applying $3 \mathrm{~mL}$ of inoculum onto the venter. Animals were placed in

135 individual $40 \mathrm{~mL}$ containers for $6 \mathrm{~h}$, and then transferred back into their terraria. Control animals

136 were mock-inoculated using uninfected agar plates (See table 1 for sample sizes).

$138 \quad 2.2 .2$ Caspase assay

139 L. v. alpina used in the caspase 3/7 assay were inoculated following the same protocol as

140 for P. corroboree above. Control animals were mock-inoculated using uninfected agar plates.

\section{$142 \quad 2.3$ Data Collection}

143 Each week animals were swabbed for $B d$ infection (see below), weighed to the nearest

$1440.01 \mathrm{~g}$ with a digital scale, and measured snout to venter (SVL) to the nearest $0.1 \mathrm{~mm}$ with dial

145 callipers. Animals were euthanized with an overdose of MS-222 when severe clinical signs of

146 chytridiomycosis were displayed (irregular skin slough, leg redness, inappetence, lethargy, loss

147 of righting reflex) and animals appeared moribund in accordance with animal ethics. Clinical 
148 signs of disease were seen by Litoria v. alpina from days 52-70 and by P. corroboree from days

149 45-83. The experiment ended on day 90, when all control and remaining exposed animals were

150 euthanized.

$151 \quad$ 2.3.1 TUNEL Assay

152 In order to explore cell death in the epidermis of animals that experienced a light

153 infection, 3 P. corroboree were euthanized on day 21 post inoculation. This group of animals

154 will hereby be called "Early $B d+$ ".

155 2.3.2 Caspase Assay

156 For the L. v. alpina in the caspase 3/7 assay, toe clips were removed from each animal at

157 the second phalange and immediately frozen at $-80^{\circ} \mathrm{C}$. Toe clips were removed weekly until

158 week 3 , and then fortnightly until the end of the experiment.

1602.4 Testing for $\mathrm{Bd}$

161 We tested for $B d$ infection by using qPCR on skin swabs (Boyle et al., 2004). We used a

162 standard protocol that involved 45 strokes per animal with a sterile rayon-tipped swab (MW-113,

163 Medical Wire \& Equipment), five on the middle of the venter, five on each side of the venter,

164 five on each thigh, and five on the ventral surface of each hand and foot. The swab was gently

165 rotated during and between strokes to ensure the greatest amount of DNA was gathered on the

166 swab. Genomic DNA was extracted from the swabs using the Prepman Ultra kit and 2 minutes of

167 bead beating to break apart the fungal cell walls. The extract was analysed using quantitative

168 PCR following Boyle et al. (2004), in singlicate (Kriger, Hero \& Ashton, 2006; Skerratt et al.,

169 2011; Brannelly et al., 2015b) with a positive and negative control, and a series of dilution 
170 standards (made in house from a local Australian $B d$ isolate) in order to determine zoospore

171 equivalents (ZE) per sample.

172

$173 \quad 2.5$ TUNEL Assay

174 Upon euthanasia, a subset of L. v. alpina animals ( $\mathrm{n}=2$ control and $\mathrm{n}=2$ exposed), and

$175 P$. corroboree $(\mathrm{n}=5 B d$ - control, $\mathrm{n}=3$ Early $B d+$ animals with light $B d$ infection, and $\mathrm{n}=10$

176 Late $B d+$ animals at morbidity) (Table 1) were dissected for skin samples (one sample each from

177 the dorsum, venter and thigh, although no thigh skin was taken for the $P$. corroboree Early $B d+$

178 animals because that skin was used in a transcriptomics project). Skin was fixed in $4 \%$ phosphate

179 buffered formaldehyde for $2 \mathrm{~h}$, and tissues were transferred to $80 \%$ ethanol prior to embedding in

180 paraffin wax for histological preparation. Routine histological techniques were used to prepare

181 the tissues for light microscopy following standard methods (Woods \& Ellis, 1994). Tissues

182 were dehydrated in a graded series of ethanol, cleared with xylene, and embedded in paraffin (all

183 three skin samples in one block). Tissues were serially sectioned at $5 \mu \mathrm{m}$, affixed to hydrophilic

184 glass slides with four serial histosections per slide. Three slides were made per tissue section

185 from the three different areas of the skin per animal and stained in the following order: the first

186 slide was stained with hematoxylin followed by eosin counterstaining (H\&E). The next two

187 slides were processed with TUNEL assay following manufacturer's instructions (ApopTag® Red

188 In Situ Apoptosis Detection Kit, Merck Millipore), followed with a DAPI counterstain. The first

189 of the slides used in TUNEL were the assay slides (where we assessed number of apoptotic cells)

190 and the second slide was a quality control test (with two histosections used as a positive control

191 and the last two as a negative control). For the TUNEL assay slides, cells were counted using

192 fluorescent microscopy at 200x magnification under DAPI fluorescence, then the same section 
193 counted for TUNEL positive staining, indicating apoptotic cells. At least 100 cells per animal

194 were counted per skin section. At least 100 cells per animal were counted per randomly chosen

195 skin section. To reach 100 cells, all cells were counted within a field of view. If a field of view

196 contained less than 100 cells, another field of view was selected and counted entirely. The H\&E

197 stained histosections were used to ensure the site of infection were the areas used in the TUNEL

198 assay to count apoptotic cells.

199

200

2.6 Caspase 3/7 Assay

$201 \quad$ Frozen toe clip samples were extracted in $100 \mu \mathrm{L}$ Buffer A (25 mM HEPES pH 7, 5 mM

$202 \mathrm{MgCl}_{2}$ ) with two $3.2 \mathrm{~mm}$ stainless steel beads in a $1.5 \mathrm{~mL}$ microtube. Samples were lysed by

203 four cycles of $1 \mathrm{~min}$ bead beating followed by $3 \mathrm{~min}$ on ice. Samples were then centrifuged at

$2044^{\circ} \mathrm{C}$ for $5 \mathrm{~min}$ at $12,000 \mathrm{x}$. Supernatant was collected and used in the assay. As toe samples

205 were very small, reaction volumes were kept to a minimum. Protein concentration of each toe

206 was determined to standardise the sample sizes for the caspase assay. Concentration was

207 quantified using the Bradford assay, with $10 \mu \mathrm{L}$ Coomassie Bradford reagent (Pierce) and $10 \mu \mathrm{L}$

208 of protein extract mixed and incubated at room temperature for $2 \mathrm{~min}$. The samples and BSA

209 standards were run in duplicate or triplicate in a 384 well plate, and the absorbance was

210 measured at $595 \mathrm{~nm}$ (POLARstar Omega, BMG Labtech). Caspase 3/7 assay (Caspase Glo® 3/7,

211 Promega) was performed in triplicate in a 384 well plate with $10 \mu \mathrm{L}$ Caspase Glo reagent and 10

$212 \mu \mathrm{L}$ protein extract. After mixing, the reactions were incubated in the dark at room temperature

213 for $30 \mathrm{~min}$, after which luminescence was measured (POLARstar Omega, BMG Labtech)

214 (caspase activity). All samples of animals that had severe clinical signs of chytridiomycosis $(\mathrm{n}=$

215 4), all control samples $(\mathrm{n}=8)$, and a randomised subset of animals that cleared $B d$ infection $(\mathrm{n}=$ 
216 11) were analysed. Only samples through week 7 post inoculation were run, which is the last

217 sampling point where all animals with severe infection were alive in order to ensure statistical

218 validity of the $B d+$ animals.

219

220

2.7 Statistical Analysis

221

2.7.1 Infection load

222

Infection loads, or ZE determined from qPCR, of animals were log base 10 transformed.

223 Clinical infections were defined as showing signs of disease with high $B d$ loads by qPCR (ie

224 greater than $1000 \mathrm{ZE})$. An animal was considered cleared of infection if the animal was qPCR

225 negative for $\mathrm{Bd}$ for at least three weeks. For the L. v. alpina involved in the caspase trial, we

226 defined three infection statuses: control animals, animals that demonstrated severe clinical signs

$227(B d+)$ and animals that cleared $B d$ infection ( $B d$ cleared) animals. $B d+$ animals were compared

228 with $B d$-cleared animals in infection intensity using linear mixed effects models; where

229 individual was repeated, the response variable was infection intensity, and fixed effects were

230 week, infection status and week*infection status. Overall infection load for each group (L. v.

231 alpina caspase trial: $B d$ cleared and $B d+; P$. corroboree TUNEL assay: Early $B d$ infection and

232 Late $B d$ infection) were determined by averaging infection load at date of death for $P$.

233 corroboree and infection load through all time points for L. v. alpina and determining the effect

234 size using Cohen's $d$ statistic (Altman, 1991) in Microsoft Excel in which a large effect is when $235 d>0.8$.

236

237 2.7.2 TUNEL assay statistics 
238 The proportion of TUNEL positive cells to TUNEL negative cells in infected animals and

239 control animals was compared using Pearson's Chi-Squared test for association. Each tissue type

240 (dorsal, ventral and thigh skin) was analysed as a separate chi-squared test. Following the

241 association test, the strength of association was determined by an odds ratio analysis for TUNEL

242 positive and negative cells of each tissue type. The odds ratio analysis was performed in

243 Microsoft Excel (Altman, 1991). Sample sizes for L. v. alpina were too small to determine

244 significance ( $\mathrm{n}=2 B d+, \mathrm{n}=2 B d$-cleared), so trends were noted following the chi-squared and

245 odds ratio tests, while significance was determined in the $P$. corroboree samples $(\mathrm{n}=5$ control, $\mathrm{n}$

$246=3$ Early $B d+$ and $\mathrm{n}=10$ Late $B d+$ ).

248 2.7.3 Caspase assay statistics

249 Caspase 3/7 activity was calculated as caspase activity over protein concentration per

250 sample, and then $\log$ base 10 transformed. Weeks 1, 2, 3, 5 and 7 were analysed for the three

251 infection statuses, control, $B d+$ and $B d$-cleared. Caspase activity was assessed using linear mixed

252 effects models; where the response variable was caspase activity, individual was repeated, and

253 week, infection status and week*infection status were fixed effects. If infection status*week was

254 a significant integration we used one-way ANOVAs and Bonferroni's post hoc test to determine

255 in which specific weeks the infection status groups differed in caspase activity. To determine the

256 change in caspase activity each week, linear mixed effects models were used with the same

257 parameters as above, except the response variable was change in caspase activity. To determine

258 which weeks change in caspase activity varied between groups, one-way ANOVAs were

259 performed using Bonferroni's post hoc test. The association between caspase activity and

260 infection intensity was performed using a linear regression in $B d$ inoculated animals only. In 
261 order to determine if week or status has an effect a general linear model (GLM) was performed;

262 where $\log _{10}$ (Caspase) was compared with infection status, week and $\log _{10}(\mathrm{ZE})$. All analyses were

263 performed using SPSS (v21) unless otherwise stated.

264

265

\subsection{Animal Ethics}

266

Animal ethics was approved by James Cook University in applications A1897 and A2171

267 for L. v. alpina and A1875 for P. corroboree.

268

269

3. Results.

270

\subsection{Bd Infection}

271

Infection progressed as expected for the TUNEL assay individuals: all P. corroboree

272

animals inoculated with $B d$ developed clinical disease, except for the three individuals

273

euthanized at day 21 and represented as Early $B d+$. Animals with clinical disease (Late $B d+$ )

274

survived between 22 and 83 days post inoculation (average of 59.6 days) and their average

275

infection load at date of death was a near to 1000 fold higher infection load (793.3 time increase

276

in ZE) than the infection load of animals with light infection loads (Early $B d+$ ), which were

277

euthanized on day 21 post inoculation (Late $B d+=5.19 \log _{10}(\mathrm{ZE})+/-0.34$; Early $B d+=2.29$

278

$\left.\log _{10}(\mathrm{ZE})+/-0.89 ; \mathrm{d}=3.04\right)$. In $B d$ inoculated L. v alpina animals $(\mathrm{n}=6)$ all developed clinical

279

chytridiomycosis and survived 39-63 days post inoculation (average of 52.7 days) and their

280 average infection load at date of death was $3.57 \log _{10}(\mathrm{ZE})+/-0.75$.

281

Of the 27 L. v. alpina inoculated in the caspase infection experiment, all became infected,

282 but only four developed severe chytridiomycosis. The first animal died on day 58 after

283 inoculation and the last on day 71 (average of 63 days). All animals that did not develop severe 
284 chytridiomycosis had cleared infection by week 12 post-inoculation. The factors that influenced

285 infection load were week, infection status and week*status (linear mixed effects model: week,

$286 \mathrm{~F}_{11}=5.425, \mathrm{p}<0.01 ;$ infection status, $\mathrm{F}_{1}=23.763, \mathrm{p}<0.01$; week*status, $\left.\mathrm{F}_{9}=3.071, \mathrm{p}<0.01\right)$

287 (Fig. 1). Litoria v. alpina animals that developed severe chytridiomycosis had, on average of all

288 time points, a near 200x higher infection load than animals that cleared infection (194 time

289 increase in ZE) $\left(\right.$ Died $=3.09+/-1.22 \log _{10}(\mathrm{ZE})$; Cleared $\left.=0.80+/-1.28 \log _{10}(\mathrm{ZE})\right)($ Cohen's d 290 statistic $=1.30)$.

291

292 3.2 TUNEL Assay

There was more cell death in infected animals compared with uninfected animals in both

L. v. alpina and P. corroboree. The location of TUNEL positive cells in situ differed in $B d+$ and control animals of both species. In control animals, low levels of background TUNEL positive cells were evenly distributed throughout the epidermal and dermal layers of the skin (Fig. 2A), but in the $B d+$ animals, the TUNEL positive cells appeared more frequently in the epidermis (Fig. 2B). On microscopic examination of the H\&E stained sections, clumped $B d$ sporangia were observed to be scattered through the ventral and thigh areas of skin, but none were seen in the dorsum of either species (Late $B d+$ ), or in the P. corroboree with light infections (Early $B d+$ ). TUNEL positive cells appeared to be more concentrated at infection foci (Fig. 2C), but were also more widespread over the epidermis and in deeper epidermal layers than $B d$. infected with $B d$ in both early and late infection (Fig. 3A). In the thigh skin, Late $B d+$ animals had 12.01 (95\% CI: $4.92-26.30$; Odds Ratio: $\mathrm{Z}=5.46, \mathrm{p}<0.01)$ times more TUNEL positive cells than control animals (Pearson's Chi Squared: $\chi^{2}{ }_{1}=44.30, \mathrm{p}<0.01$ ). In the venter skin, Late 
$307 B d+$ animals have $22.31(95 \%$ CI 5.25 - 94.82) times more TUNEL positive cells than control

308 animals (Odds Ratio: $\mathrm{Z}=4.21, \mathrm{p}<0.01)$ and $2.16(95 \% \mathrm{CI} 1.15-4.03)$ times more TUNEL

309 positive cells than Early $B d+$ animals (Odds Ratio: $\mathrm{Z}=4.21, \mathrm{p}<0.01$ ). The Early $B d+$ animals

310 had $10.33(95 \%$ CI 2.37 - 45.067) times more TUNEL positive cells than control animals in the

311 venter skin (Odds Ratio: $Z=3.11, p<0.01$; Pearson's Chi Squared: $\chi^{2}{ }_{2}=33.45, p<0.01$ ). In the

312 dorsal skin, the Late $B d+$ animals had 14.38 (95\% CI $3.32-62.24)$ times more TUNEL positive

313 cells than control animals (Odds Ratio: $\mathrm{Z}=3.57, \mathrm{p}<0.01$ ) and Early $B d+$ animals had 19.88

314 (95\% CI $4.67-84.20)$ times more TUNEL positive cells than control animals (Odds Ratio: $Z=$

$3154.05, \mathrm{p}<0.01$; Pearson's Chi Squared: $\left.\chi^{2}{ }_{2}=29.45, \mathrm{p}<0.01\right)$ but there was no difference

316 observed in TUNEL positive cells of the dorsum in Early and Late $B d+$ animals (Fig. 3A).

317 Due to the small sample sizes for infected and control L. v. alpina $(\mathrm{n}=2$ for each group),

318 only trends could be determined. But there was a higher proportion of TUNEL positive cells in

319 the venter and the thigh skin with no observable difference in the dorsal skin (Fig. 3B)

320 (Pearson's Chi Squared: Venter skin, $\chi^{2}{ }_{1}=5.38, \mathrm{p}=0.02$; Thigh skin, $\chi^{2}{ }_{1}=9.198, \mathrm{p}<0.01$,

321 Dorsal skin: $\left.\chi^{2}{ }_{1}=1.694, \mathrm{p}=0.19\right)$.

322

323

3.3 Caspase 3/7 Assay

324

Caspase activity was positively correlated with infection load in inoculated $L$. v. alpina

325

animals (Pearson's Correlation: $\mathrm{R}_{64}=0.463, \mathrm{p}<0.01$; Linear Regression: $\mathrm{F}_{1,62}=16.943, \mathrm{p}<0.01$ )

326 (Fig. 4). However, there was no overall difference between the animals that cleared infection (Bd

327 cleared $)$ and those that developed severe chytridiomycosis $(B d+)\left(\mathrm{GLM}: \mathrm{F}_{1}=0.079, \mathrm{p}=0.685\right)$,

328 or between weeks (GLM: $\left.\mathrm{F}_{4}=0.226, \mathrm{p}=0.717\right)$. 
There was a difference in total caspase activity over time among the three groups

330 (control, $B d+$ and $B d$ cleared). The three groups differed over week and week*disease status

331 (Linear mixed effects model: week, $\mathrm{F}_{4}=11.974, \mathrm{p}<0.01$; week* status, $\mathrm{F}_{8}=2.139, \mathrm{p}=0.037$ ).

332 There was no effect of week on the $B d$ - control group (Mixed model: $\left.\mathrm{F}_{4}=2.463, \mathrm{p}=0.069\right)($ Fig.

333 5A). At week 3, there was $48.36 \%$ less $\log _{10}$ caspase activity in the $B d+$ compared with the

334 control animals, and $41.63 \%$ less activity in the $B d$ cleared animals compared with the control 335 animals (ANOVA: $\mathrm{F}_{2,18}=5.512, \mathrm{p}=0.014$; Bonferroni Post-Hoc: $B d-\mathrm{v} B d+, \mathrm{p}=0.046, \mathrm{~d}=$ $3361.408 ; B d-\mathrm{v} B d$ cleared, $\mathrm{p}=0.028, \mathrm{~d}=0.923)$.

337 When investigating the change in caspase activity each week over the first seven weeks 338 post inoculation, there was a difference among the three groups, with week and week*disease 339 status as important factors (Mixed Model: week, $F_{3}=5.764, p<0.01$; week*status, $F_{6}=3.044, p$ $340=0.01$ ), but there was no effect of week on the $B d$ - control group (Mixed model: $\mathrm{F}_{3}=20.004, \mathrm{p}$

$341=0.371)($ Fig. 5B). The change in caspase activity between weeks 3 and 5 differed significantly

342 among the three groups, with the $B d+$ animals increasing in caspase $3 / 7$ activity 15.35 times the 343 change in control animals, and 2.162 times the change in cleared animals (ANOVA: $\mathrm{F}_{2,25}=$

344 10.65, $\mathrm{p}<0.01$; Bonferroni Post-Hoc: control v $B d+, \mathrm{p}<0.01, \mathrm{~d}=2.519 ; B d+\mathrm{v} B d$ cleared, $345 \mathrm{p}<0.01, \mathrm{~d}=1.241)$.

347 4. Discussion.

In this study we explored cell death and apoptosis in the epidermis of $B d$ susceptible 349 species as a potential mechanism of disease resistance or cutaneous pathology of

350 chytridiomycosis. We tested the hypothesis that cell death and apoptosis was correlated with

351 infection intensity and host survival, and further we hypothesized that if apoptosis was a useful 
352 immune response, animals that cleared infection would have higher rates initially or at the time

353 of Bd reductions. We found that cell death does indeed increase drastically during clinical

354 chytridiomycosis as demonstrated through the in situ TUNEL assay, and because caspase 3/7

355 levels were correlated with infection load, suggesting that cell death is pathology of $B d$. But

356 because animals that cleared infection had relatively low caspase levels, and did not differ from

357 the animals that eventually developed chytridiomycosis in early weeks following exposure, this

358 does not support our hypothesis that cell death and apoptosis was a useful immune response to

$359 B d$ infection.

360 We found an increase in cell death in the epidermis of infected P. corroboree and L.v.

361 alpina compared to the control animals using in situ TUNEL assay, consistent with the apoptosis

362 suggested previously by microscopy (Berger et al., 2005; Pasmans et al., 2010; Brutyn et al.,

363 2012). TUNEL positive cells were located near the site of infection, and occurred on the ventral

364 surface of the animal (thigh and venter skin); but not on the dorsum in L. v. alpina. However,

365 Pseudophryne corroboree demonstrated an increase in TUNEL positive cells as infection

366 progressed in all skin tissues. The location of TUNEL positive cells within the epidermal layers,

367 and their increase over time, is consistent with infection of $B d$ being the cause of epidermal cell 368 death.

369 Our qualitative observation of more TUNEL positive cells in the venter and thigh skin of

$370 \mathrm{Bd}$ infected animals is consistent with the pattern of $\mathrm{Bd}$ distribution noted in similar species.

371 Studies measuring $B d$ infection over the body in two Australian hylids (Litoria caerulea and

372 Litoria genimaculata), showed the dorsum was uninfected or lightly infected, with higher loads

373 on abdomen and thighs (Berger, Speare \& Skerratt, 2005; North \& Alford, 2008). We did not

374 quantify $B d$ loads at each skin site in our two species, but noted a similar pattern by histology 
375 with no sporangia seen on dorsal skin. In P. corroboree it was unexpected that increased cell

376 death occurred in dorsal skin. This site distribution, together with the diffuse staining in infected

377 sites, shows that cell death is not localised to infected and adjacent cells and may be associated

378 with diffusion of pro-apoptotic factors from the host or pathogen.

$379 \quad$ For effector caspase $3 / 7$ activity in $L$. v. alpina, $B d$ exposed animals initially

380 demonstrated stable and low levels of apoptosis early in infection (1-3 weeks), despite detectable

$381 B d$ loads (Fig. 1, 5A). This observed lower caspase activity early in infection suggests that $B d$

382 may suppress apoptosis in order to establish infection, which is particularly prominent at week 3

383 after inoculation. If the host is able to overcome infection, the caspase 3/7 levels gradually rise

384 and return to normal. However, in animals that eventually displayed clinical signs of

385 chytridiomycosis there was then a rapid and sustained increase of caspase activity over weeks 3-

3865 (Fig. 5B), which correlates with the timing of high pathogen burden (Fig. 1). This rapid

387 increase is not observed for animals that clear infection, suggesting that rapidly increasing 388 apoptosis was not beneficial and may be a mechanism of pathogenesis by $B d$ because it was 389 correlated with an increase in infection load and mortality. However, it remains possible that

390 increased apoptosis is a failed host response to higher burdens in these individuals.

391 Such pathology of initial suppression of apoptosis followed by a rapid increase has been

392 witnessed in other pathogens such as Shigella flexneri, a bacterium causing diarrhea in humans.

393 The pathogen uses a dual cell death control strategy by producing cytoprotective factors early in

394 infection to aid in replication, followed by necrotic cell death signals later in the infection to

395 enable transmission and host tissue damage (Carneiro et al., 2009). While the apoptotic effect of

$396 B d$ on amphibian lymphocytes in vitro is known (Fites et al., 2014), host and pathogen

397 mechanisms for this phenomenon are still unclear. Therefore, further experiments are required to 
398 confirm whether $B d$ can stimulate or suppress apoptosis in epidermal cells. Cell-specific effects

399 are seen in other pathogens, for example, Salmonella enterica induces cell death in macrophages

400 (Fink \& Cookson, 2006), but suppresses apoptosis in epithelial cells (Knodler, Finlay \& Steele-

401 Mortimer, 2005), showing that a pathogen can behave differently in different cell types.

402 Interestingly, while there is evidence of a higher proportion of epidermal cell death in

403 infected animals at morbidity through the TUNEL endpoint assay, we observed no difference in

404 caspase 3/7 activities between $B d+$ and $B d$ - animals at week 7. This discrepancy may be

405 explained by the two different measures of cell death. Caspase 3/7 is an effector enzyme integral

406 to the caspase pathway, but other enzymes within the caspase pathway may also be effective

407 indicators of apoptosis. For example, caspase 1 is involved in the inflammatory response in vivo.

408 Furthermore, caspase 8 (extrinsic pathway) and 9 (intrinsic pathway) are both known to be active

409 in response to $B d$ in lymphocytes in vitro (Fites et al., 2013), and further work should explore the

410 levels of these caspases in order to separate activation in the intrinsic and extrinsic pathways.

411 Furthermore, the last caspase data point was measured at week 7, which is 1-3 weeks prior to the

412 frogs becoming moribund when TUNEL assays were conducted. Therefore, the caspase activity

413 may have increased later in the infection if samples were taken until the time of death. Site

414 specific apoptosis may also affect the caspase 3/7 results, as this time course experiment required

415 sampling of toes rather than body skin.

416 It must also be noted that while the TUNEL assay is most often used to explore apoptotic

417 cells, it measures DNA damage, which can be caused by other cell death mechanism like

418 necrosis and pyroptosis (Kelly et al., 2003). Therefore, the increase in assay positive cells at

419 morbidity may be caused by non-apoptotic cell death pathways that do not involve caspase

420 enzymes. Non-caspase mediated cell death might explain the pattern of increased positive 
421 TUNEL assay in the Early $B d+P$. corroboree, which was not mirrored in the caspase assay of $L$.

422 v. alpina. Alternatively the two species might exhibit different host-pathogen interactions.

This study investigating the role of apoptosis through in situ TUNEL assay and caspase

$4243 / 7$ presence in the epidermis demonstrates only the initial stages of exploring apoptosis in vivo.

425 The early signs of apoptosis suppression in exposed animals suggest that suppression of

426 apoptosis may be used initially by the pathogen in order to establish infection. And the steep

427 increase in apoptosis and cell death in animals that succumbed to disease could explain the

428 disruption to epidermal ion transport that ultimately causes cardiac arrest in clinical

429 chytridiomycosis, although further work on the causal mechanisms of pathogenesis is needed.

430 While more research is needed to determine how apoptosis influences disease outcomes in hosts

431 able to clear infection, these results suggest that apoptosis can be important in the pathogenesis 432 of $B d$.

433

434 Acknowledgements.

435 We would like to thank D. Tegtmeier, C. De Jong, J. Hawkes, K. Fossen, S. Percival, M.

436 McWilliams, L. Bertola, M. Stewart, N. Harney, and T. Knavel for data collection and husbandry

437 assistance, and M. Merces for help with dissections. We thank M. McFadden, P. Harlow and

438 Taronga Zoo for raising the L. v. alpina, and G. Marantelli for raising the P. corroboree. We

439 thank F. Pasmans, A. Martel for advice on apoptosis assays, C. Constantine, A. Kladnik and R.

440 Webb for assistance with TUNEL assay, and T. Emeto and W. Weßels for help with protocol

441 and kit for caspase 3/7 assay.

442

443 References. 
445 Altman, D.G., 1991. Practical Statistics for Medical Research. Chapman \& Hall, London.

446 Ashida, H., Mimuro, H., Ogawa, M., Kobayashi, T., Sanada, T., Kim, M., Sasakawa, C., 2011.

447 Cell death and infection: a double-edged sword for host and pathogen survival. J. Cell Biol.

$448 \quad$ 195, 931-42. doi:10.1083/jcb.201108081

449 Barber, G.N., 2001. Host defense, viruses and apoptosis. Cell Death Differ. 8, 113-126.

$450 \quad$ doi: $10.1038 /$ sj.cdd. 4400823

451 Bataille, A., Cashins, S.D., Grogan, L., Skerratt, L.F., Hunter, D., McFadden, M., Scheele, B.,

452 Brannelly, L.A., Macris, A., Harlow, P.S., Bell, S., Berger, L., Waldman, B., Waldman, B.,

453 2015. Susceptibility of amphibians to chytridiomycosis is associated with MHC class II

$454 \quad$ conformation. Proceeding R. Soc. B 282, 20143127.

455 Berger, L., Hyatt, A.D., Speare, R., Longcore, J.E., 2005a. Life cycle stages of the amphibian

456 chytrid Batrachochytrium dendrobatidis. Dis. Aquat. Organ. 68, 51-63.

457 doi:10.3354/dao068051

458 Berger, L., Speare, R., Skerratt, L.F., 2005b. Distribution of Batrachochytrium dendrobatidis and

459 pathology in the skin of green tree frogs Litoria caerulea with severe chytridiomycosis. Dis.

$460 \quad$ Aquat. Organ. 68, 65-70. doi:10.3354/dao068065

461 Boyle, D.G., Boyle, D.B., Olsen, V., Morgan, J.A.T., Hyatt, A.D., 2004. Rapid quantitative

462 detection of chytridiomycosis (Batrachochytrium dendrobatidis) in amphibian samples

463 using real-time Taqman PCR assay. Dis. Aquat. Organ. 60, 141-8. doi:10.3354/dao060141

464 Brannelly, L.A., Berger, L., Marrantelli, G., Skerratt, L.F., 2015a. Low humidity is a failed

465 treatment option for chytridiomycosis in the critically endangered southern corroboree frog.

466 Wildl. Res. 42, 44-49. 
467 Brannelly, L.A., Hunter, D.A., Lenger, D., Scheele, B.C., Skerratt, L.F., Berger, L., $2015 b$.

468 Dynamics of chytridiomycosis during the breedings season in an Australian alpine

469 amphibian. PLoS One 10, e0143629. doi:10.1371/journal.pone.0143629

470

471

472

473

474

475

476

477

478

479

480

481

482

483

484

485

486

487

488

489

Brannelly, L.A., Hunter, D.A., Skerratt, L.F., Scheele, B.C., Lenger, D., McFadden, M.S., Harlow, P.S., Berger, L., 2016. Chytrid infection and post-release fitness in the reintroduction of an endangered alpine tree frog. Anim. Conserv. 19, 153-162. doi:10.1111/acv.12230

Brannelly, L.A., Skerratt, L.F., Berger, L., 2015c. Treatment trial of clinically ill corroboree frogs with chytridiomycosis with two triazole antifungals and electrolyte therapy. Vet. Res. Commun. 39, 179-187. doi:10.1007/s11259-015-9642-5

Brannelly, L.A., Webb, R., Skerratt, L.F., Berger, L., 2016a. Amphibians with infectious disease increase their reproductive effort: evidence for the terminal investment hypothesis. Open Biol. 6, 1-24. doi:10.1098/rsob.150251

Brannelly, L.A., Webb, R.J., Skerratt, L.F., Berger, L., 2016b. Effects of chytridiomycosis on hematopoietic tissue in the spleen, kidney and bone marrow in three diverse amphibian species. Pathog. Dis. In Press.

Brutyn, M., D’Herde, K., Dhaenens, M., Van Rooij, P., Verbrugghe, E., Hyatt, A.D., Croubels, S., Deforce, D., Ducatelle, R., Haesebrouck, F., Martel, A., Pasmans, F., 2012. Batrachochytrium dendrobatidis zoospore secretions rapidly disturb intercellular junctions in frog skin. Fungal Genet. Biol. 49, 830-7. doi:10.1016/j.fgb.2012.07.002

Carneiro, L.A.M., Travassos, L.H., Soares, F., Tattoli, I., Magalhaes, J.G., Bozza, M.T., Plotkowski, M.C., Sansonetti, P.J., Molkentin, J.D., Philpott, D.J., Girardin, S.E., 2009. Shigella induces mitochondrial dysfunction and cell death in nonmyleoid cells. Cell Host 
491 Cashins, S.D., Grogan, L.F., McFadden, M., Hunter, D., Harlow, P.S., Berger, L., Skerratt, L.F., 492 2013. Prior infection does not improve survival against the amphibian disease 493 chytridiomycosis. PLoS One 8, e56747. doi:10.1371/journal.pone.0056747

494 Ellison, A.R., Tunstall, T., Direnzo, G. V., Hughey, M.C., Rebollar, E.A., Belden, L.K., Harris,

495 R.N., Ibanez, R., Lips, K.R., Zamudio, K.R., 2014. More than skin deep: Functional 496 genomic basis for resistance to amphibian chytridiomycosis. Genome Biol. Evol. 7, 286298. doi:10.1093/gbe/evu285

498

499

500

501

502

503

504

505

506

507

508

509

510

511

512

Fadeel, B., Orrenius, S., 2005. Apoptosis: a basic biological phenomenon with wide-ranging implications in human disease. J. Intern. Med. 258, 479-517. doi:10.1111/j.13652796.2005.01570.x

Faherty, C.S., Maurelli, A.T., 2008. Staying alive: bacterial inhibition of apoptosis during infection. Trends Microbiol. 16, 173-80. doi:10.1016/j.tim.2008.02.001

Fink, S.L., Cookson, B.T., 2005. Apoptosis, pyroptosis, and necrosis: mechanistic description of dead and dying eukaryotic cells. Infect. Immun. 73, 1907-16. doi:10.1128/IAI.73.4.19071916.2005

Fink, S.L., Cookson, B.T., 2006. Caspase-1-dependent pore formation during pyroptosis leads to osmotic lysis of infected host macrophages. Cell. Microbiol. 8, 1812-25. doi:10.1111/j.1462-5822.2006.00751.x

Fites, J.S., Ramsey, J.P., Holden, W.M., Collier, S.P., Sutherland, D.M., Reinert, L.K., Gayek, A.S., Dermody, T.S., Aune, T.M., Oswald-Richter, K., Rollins-Smith, L.A., 2013. The invasive chytrid fungus of amphibians paralyzes lymphocyte responses. Science. 342, 366369. doi:10.5061/dryad.878m3 
513 Fites, J.S., Reinert, L.K., Chappell, T.M., Rollins-Smith, L.A., 2014. Inhibition of local immune

514 responses by the frog-killing fungus Batrachochytrium dendrobatidis. Infect. Immun. 82,

515 4698-4706. doi:10.1128/IAI.02231-14

516 Galluzzi, L., Aaronson, S.A., Abrams, J., Alnemri, E.S., Andrews, D.W., Baehrecke, E.H., 517 Bazan, N.G., Blagosklonny, M. V, Blomgren, K., Borner, C., Bredesen, D.E., Brenner, C., 518 Castedo, M., Cidlowski, J.A., Ciechanover, A., Cohen, G.M., De Laurenzi, V., De Maria, 519 R., Deshmukh, M., Dynlacht, B.D., El-Deiry, W.S., Flavell, R.A., Fulda, S., Garrido, C., 520 Golstein, P., Gougeon, M.-L., Green, D.R., Gronemeyer, H., Hajnóczky, G., Hardwick, 521 J.M., Hengartner, M.O., Ichijo, H., Jäättelä, M., Kepp, O., Kimchi, A., Klionsky, D.J., 522 Knight, R.A., Kornbluth, S., Kumar, S., Levine, B., Lipton, S.A., Lugli, E., Madeo, F., 523 Malomi, W., Marine, J.-C.W., Martin, S.J., Medema, J.P., Mehlen, P., Melino, G., Moll, 524 U.M., Morselli, E., Nagata, S., Nicholson, D.W., Nicotera, P., Nuñez, G., Oren, M., 525 Penninger, J., Pervaiz, S., Peter, M.E., Piacentini, M., Prehn, J.H.M., Puthalakath, H., Rabinovich, G.A., Rizzuto, R., Rodrigues, C.M.P., Rubinsztein, D.C., Rudel, T., Scorrano,

531 Hacker, G., 2009. Microbial Inhibitors of Apoptosis, Encylopedia of Life Sciences. John Wiley 532 L., Simon, H.-U., Steller, H., Tschopp, J., Tsujimoto, Y., Vandenabeele, P., Vitale, I., Vousden, K.H., Youle, R.J., Yuan, J., Zhivotovsky, B., Kroemer, G., 2009. Guidelines for the use and interpretation of assays for monitoring cell death in higher eukaryotes. Cell Death Differ. 16, 1093-1107. doi:10.1038/cdd.2009.44 \& Sons, Ltd, Chinchester. doi:10.1002/9780470015902.a0021984

Hasnain, S.E., Begum, R., Ramaiah, K.V.A., Sahdiev, S., Shajil, E.M., Tanejia, T.K., Mohan, 534 M., Athar, M., Sah, N.K., Krishaveni, M., 2003. Host-pathogen interactions during apoptosis. J. Biosci. 28, 349-358. 
536 Karbowski, M., Kurono, C., Wozniak, M., Ostrowski, M., Teranishi, M., Soji, T., Wakabayashi,

537 T., 1999. Cycloheximide and 4-OH-TEMPO suppress chloramphenicol-induced apoptosis

538 in RL-34 cells via the suppression of the formation of megamitochondria. Biochim.

539 Biophys. Acta 1449, 25-40.

540 Kelly, K.J., Sandoval, R.M., Dunn, K.W., Molitoris, B. a, Dagher, P.C., 2003. A novel method to

541 determine specificity and sensitivity of the TUNEL reaction in the quantitation of apoptosis.

542 Am. J. Cell Physiol. 284, C1309-18. doi:10.1152/ajpcell.00353.2002

543 Kim, J.M., Eckmann, L., Savidge, T.C., Lowe, D.C., Witthöft, T., Kagnoff, M.F., 1998.

544 Apoptosis of human intestinal epithelial cells after bacterial invasion. J. Clin. Invest. 102,

545 1815-1823. doi:10.1172/JCI2466

546 Knodler, L.A., Finlay, B.B., Steele-Mortimer, O., 2005. The Salmonella effector protein SopB

547 protects epithelial cells from apoptosis by sustained activation of Akt. J. Biol. Chem. 280,

$548 \quad 9058-64$. doi:10.1074/jbc.M412588200

549 Kriger, K.M., Hero, J.-M., Ashton, K.J., 2006. Cost efficiency in the detection of

$550 \quad$ chytridiomycosis using PCR assay. Dis. Aquat. Organ. 71, 149-54. doi:10.3354/dao071149

551 Lamkanfi, M., Dixit, V.M., 2010. Manipulation of host cell death pathways during microbial

552 infections. Cell Host Microbe 8, 44-54. doi:10.1016/j.chom.2010.06.007

553 McMahon, T.A., Sears, B.F., Venesky, M.D., Bessler, S.M., Brown, J.M., Deutsch, K., Halstead, 554 N.T., Lentz, G., Tenouri, N., Young, S., Civitello, D.J., Ortega, N., Fites, J.S., Reinert, L.K., 555 Rollins-Smith, L.A., Raffel, T.R., Rohr, J.R., 2014. Amphibians acquire resistance to live 556 and dead fungus overcoming fungal immunosuppression. Nature 511, 224-7.

557 Nogueira, C. V, Lindsten, T., Jamieson, A.M., Case, C.L., Shin, S., Thompson, C.B., Roy, C.R.,

558 2009. Rapid pathogen-induced apoptosis: a mechanism used by dendritic cells to limit

559 intracellular replication of Legionella pneumophila. PLoS Pathog. 5, e1000478. 
doi:10.1371/journal.ppat.1000478

561 North, S., Alford, R.A., 2008. Infection intensity and sampling locality affect Batrachochytrium

562 dendrobatidis distribution among body regions on green-eyed tree frogs Litoria

563 genimaculata. Dis. Aquat. Organ. 81, 177-188. doi:10.3354/dao01958

564 Parris, M.J., Cornelius, T.O., 2004. Fungal pathogen causes competitive and developmental

$565 \quad$ stress in larval amphibian communities. Ecology 85, 3385-3395.

566 Pasmans, F., Muijsers, M., Maes, S., Van Rooij, P. V., Brutyn, M., Ducatelle, R., Haesebrouck,

567 F., Martel, A., 2010. Chytridiomycosis related mortality in a midwife toad (Alytes

568 obstetricans) in Belgium. Vlaams Diergeneeskd. Tijdschr. 79, 460-462.

569 Popadic, S., Popadic, D., Ramic, Z., Stojkovic, M.M., Trajkovic, V., Milinkovic, M., Medenica,

570 L., 2006. Chloramphenicol induces in vitro growth arrest and apoptosis of human

571 keratinocytes. Cell Biol. Toxicol. 22, 371-379. doi:10.1007/s10565-006-0058-4

572 Savage, A.E., Zamudio, K.R., 2011. MHC genotypes associate with resistance to a frog-killing

573 fungus. PNAS 108, 16705-10. doi:10.1073/pnas.1106893108

574 Scheele, B.C., Hunter, D.A., Grogan, L.F., Berger, L., Kolby, J.E., McFadden, M.S., Marantelli,

575 G., Skerratt, L.F., Driscoll, D.A., 2014. Interventions for reducing extinction risk in

576 chytridiomycosis-threatened amphibians. Conserv. Biol. 28, 1195-1205.

577 doi:10.1111/cobi. 12322

578 Skerratt, L.F., Berger, L., Clemann, N., Hines, H.B., Hunter, D.A., Marrantelli, G., McFadden, M.S., Newell, D.A., Philips, A., Scheele, B.C., Brannelly, L.A., Speare, R., Versteegen, S.,

580 Cashins, S.D., West, M., 2016. Priorities for management of chytridiomycosis in Australia: 581 saving frogs from extinction. Wildl. Res. 43, 105-120

582 Skerratt, L.F., Berger, L., Speare, R., Cashins, S., McDonald, K.R., Phillott, A.D., Hines, H.B., 
Kenyon, N., 2007. Spread of chytridiomycosis has caused the rapid global decline and extinction of frogs. Ecohealth 4, 125-134. doi:10.1007/s10393-007-0093-5

Skerratt, L.F., Mendez, D., Mcdonald, K.R., Garland, S., Livingstone, J., Speare, R., 2011. Validation of diagnostic tests in wildlife: The case of chytridiomycosis in wild amphibians. J. Herpetol. 45, 444-450. doi:10.1670/10-193.1

Stuart, S.N., Chanson, J.S., Cox, N.A., Young, B.E., Rodrigues, A.S.L., Fischman, D.L., Waller, R.W., 2004. Status and trends of amphibian declines and extinctions worldwide. Science. 306, 1783-1786. doi:10.1126/science.1103538

Voyles, J., Young, S., Berger, L., Campbell, C., Voyles, W.F., Dinudom, A., Cook, D., Webb, R., Alford, R.A., Skerratt, L.F., Speare, R., 2009. Pathogenesis of chytridiomycosis, a cause

594 Weinrauch, Y., Zychlinsky, A., 1999. The induction of apoptosis by bacterial pathogens. Annu. $595 \quad$ Rev. Microbiol. 53, 155-187.

596 Woodhams, D.C., Rollins-Smith, L.A., Alford, R.A., Simon, M.A., Harris, R.N., 2007. Innate 597 immune defenses of amphibian skin: antimicrobial peptides and more. Anim. Conserv. 10, 425-428. doi:10.1111/j.1469-1795.2007.00150.x

Woodhams, D.C., Rollins-Smith, L.A., Carey, C., Reinert, L., Tyler, M.J., Alford, R.A., $2006 a$.

$600 \quad$ Population trends associated with skin peptide defenses against chytridiomycosis in 601 Australian frogs. Oecologia 146, 531-40. doi:10.1007/s00442-005-0228-8

602 Woodhams, D.C., Voyles, J., Lips, K.R., Carey, C., Rollins-Smith, L.A., 2006b. Predicted 603 disease susceptibility in a Panamanian amphibian assemblage based on skin peptide 604 defenses. J. Wildl. Dis. 42, 207-18.

Woods, A., Ellis, R. 1994. Laboratory Histopathology: A Complete Reference. Edinburgh: 606 Churchill Livingstone. 
607 Woodward, A., Berger, L., Skerratt, L.F., 2014. Short communication: in vitro sensitivity of the 608 amphibian pathogen Batrachochytrium dendrobatidis to antifungal therapeutics. Res. Vet. 609 Sci. 97, 364-366. doi:10.1016/j.rvsc.2014.06.013

610 Young, S., Speare, R., Berger, L., Skerratt, L.F., 2012. Chloramphenicol with fluid and 611 electrolyte therapy cures terminally ill green tree frogs (Litoria caerulea) with 612 chytridiomycosis. J. Zoo Wildl. Med. 43, 330-337. doi:10.1638/2011-0231.1

613 Zuo, X., Djordjevic, J.T., Bijosono Oei, J., Desmarini, D., Schibeci, S.D., Jolliffe, K. a, Sorrell, 614 T.C., 2011. Miltefosine Induces Apoptosis-Like Cell Death in Yeast via Cox9p in 615 Cytochrome c Oxidase. Mol. Pharmacol. 80, 476-485. doi:10.1124/mol.111.072322 


\section{Table}

618 Table 1. Sample sizes for all animals inoculated, and the subset of animals used in each assay.

619

Total animals $\quad$ Subset Used

Species Assay Inoculated Control $B d+\quad$ Control $B d+$ Early $B d$-cleared

Litoria v. alpina

TUNEL

6

7

2

Caspase

27

8

4

8

11

Pseudophryne corroboree TUNEL

13

6

10

5

3

620 


\section{Figure Legends.}

622 Figure 1.- Infection intensity over the course of the experiment in animals that succumbed to

623 chytridiomycosis $(B d+)(\mathrm{n}=4)$ and those that cleared infection (Cleared) $(\mathrm{n}=23)$ after week 12

624 for the Litoria verreauxii alpina in the caspase trial. Infection intensity is $\log _{10}(\mathrm{ZE})$, and error

625 bars indicate standard error.

626

627

628

629 Figure 2.- Terminal transferase-mediated dUTP nick end-labelling (TUNEL) in situ assay of

630 infected and uninfected animals. A) Bd-control thigh skin section of Pseudophryne corroboree,

631 and B) $B d+$ thigh skin section of $P$. corroboree stained by in situ TUNEL assay. The blue is

632 DAPI staining indicating nuclei of the cells, and the red is the rhodamine stain, which indicates

633 DNA fragmentation characteristically caused by apoptosis. The yellow arrow indicates the

634 position of the $B d$ cluster seen in panel C. C) $P$. corroboree section of thigh skin stained with

$635 \mathrm{H} \& \mathrm{E}$. The H\&E section is serial to panel B. There is a cluster of empty $B d$ sporangia (arrow) and

636 a few dark immature sporangia near the skin surface. For all three panels the epidermis is at the

637 top of the photos. Comparing panels B and C shows that the rhodamine stained epidermal cells

638 are concentrated around and below the cluster of $B d$ and where skin damage is visible such as

639 micro-vesicle formation between basal epidermal cells. 400x magnification and the scale bar

640 indicates $0.03 \mathrm{~mm}$.

641

642

643 
644

645 Figure 3.- The proportion of TUNEL positive (TUNEL+) cells per skin type. A) The proportion 646 of TUNEL positive apoptotic cells per skin type in $P$. corroboree with light infection intensity 647 (Early $B d+, \mathrm{n}=3$ ), animals that succumbed to disease (Late $B d+, \mathrm{n}=9)$ and $B d$ - animals $(\mathrm{n}=$ 648 10). Error bars indicate $95 \%$ confidence intervals of a proportion and * indicates a significant 649 increase in apoptotic cell proportions where $(* a)$ indicates a difference between $B d$ - and Late $650 B d+,(* \mathrm{~b})$ indicates a difference between $B d$ - and Early $B d+$, and $\left({ }^{* \mathrm{c}}\right)$ indicates a difference 651 between Early $B d+$ and Late $B d+$ skin samples. There was no thigh skin sample taken for the 652 Early $B d+$ group. B) The proportion of TUNEL positive apoptotic cells in L. v. alpina for $B d$ 653 control animals $(\mathrm{n}=2)$ and $B d+$ clinically infected animals $(\mathrm{n}=2)$, where each individual is 654 represented as a separate bar.

658 Figure 4.- The correlation between infection intensity, $\log _{10}(\mathrm{ZE})$, and caspase $3 / 7$, $659 \log _{10}$ (Caspase) of inoculated L.v. alpina over the course of the experiment. The correlation 660 between infection intensity and caspase activity is 0.463 , and the trend line has an equation of $y$ $661=(0.229) \mathrm{x}+0.939$. There is no difference between $B d+$ animals that succumbed to $B d$ infection $662(n=4)$ and animals that were inoculated and then cleared infection $(n=23)$, or between weeks of 663 infection. 
667 Figure 5.- Caspase 3/7 activity through week 7 for each group of L. v. alpina: $B d+$ that

668 succumbed $(B d+, \mathrm{n}=4)$, controls $(\mathrm{n}=8)$ and $B d$ inoculated that cleared infection (Cleared, $\mathrm{n}=$

669 23). Caspase activity is defined as the lumiunecence reading controlled for by protein

670 concentration per sample and then $\log$ base 10 transformed. A) The caspase activity $\left(\log _{10}\right.$

671 transformed) for each group per week. B) The weekly change in caspase activity $\left(\log _{10}\right.$

672 transformed) for each group. Error bars indicate standard error. *a indicates the $B d+$ group

673 differed significantly from the control group at that week, $*$ b indicates the cleared group differed

674 from the control group, and $* \mathrm{c}$ indicates that the $B d+$ group differed from the Cleared group.

675 
676 Figure Legends.

677 Figure 1

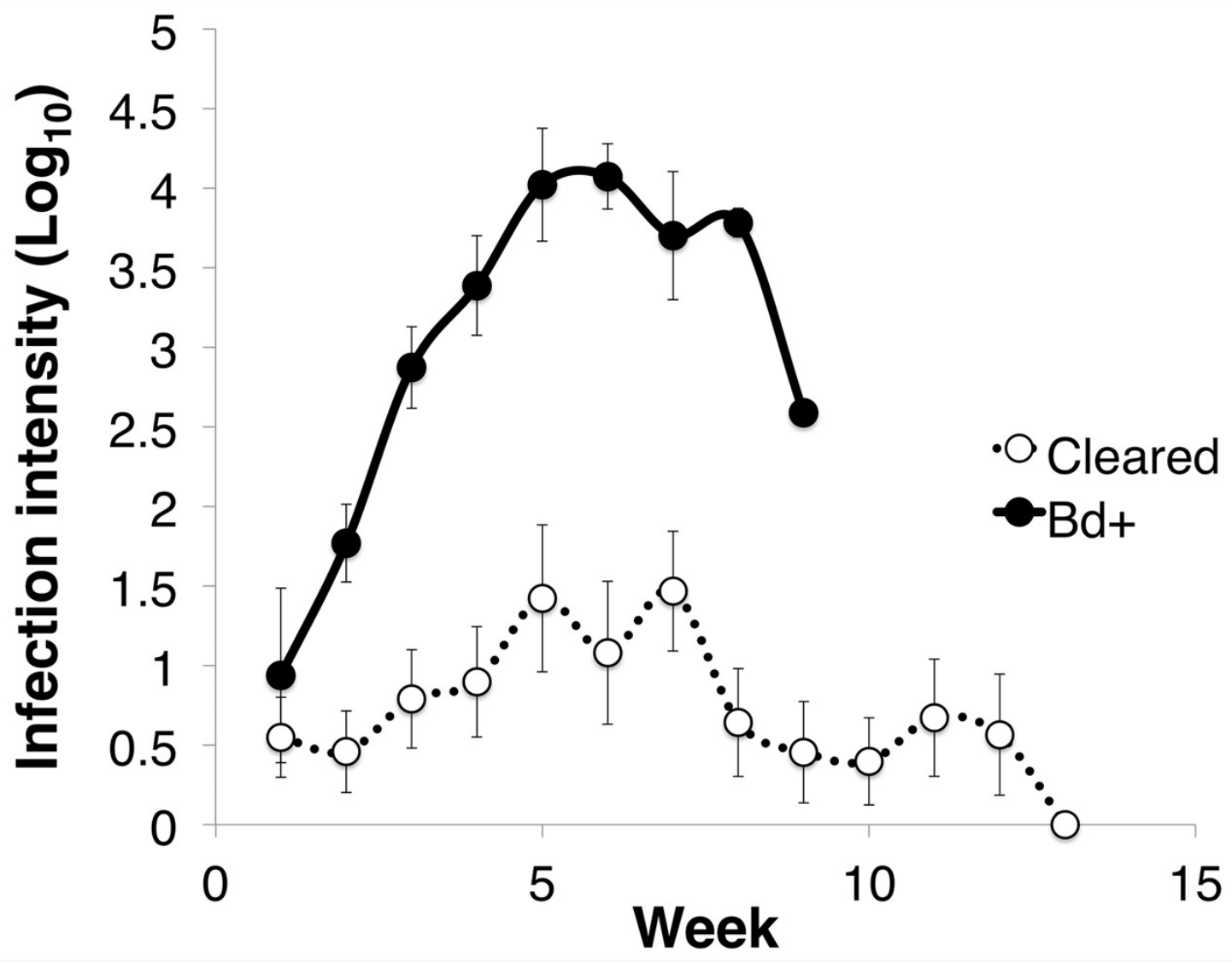




\section{PeerJ}

679 Figure 2
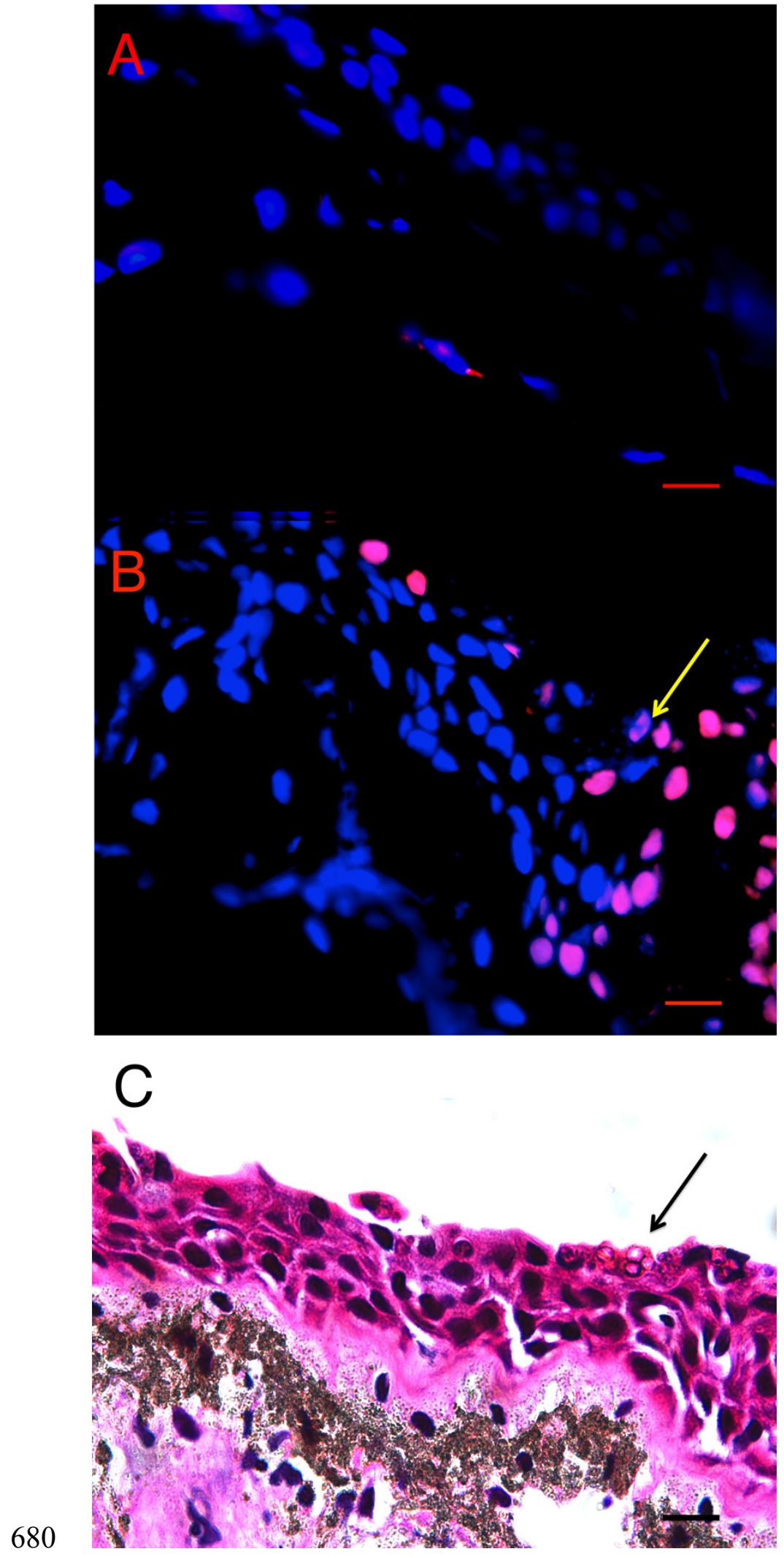
681 Figure 3

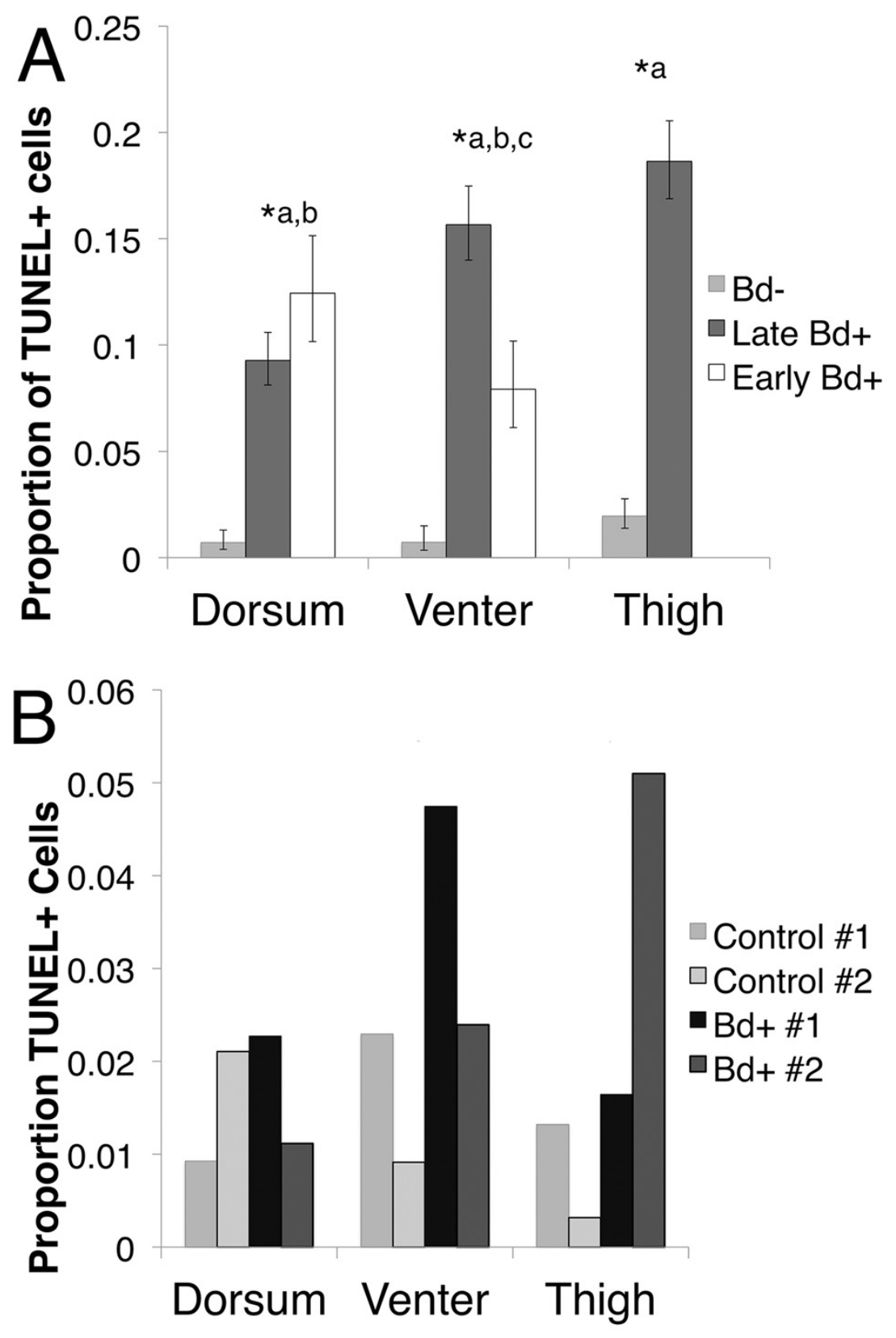


683 Figure 4

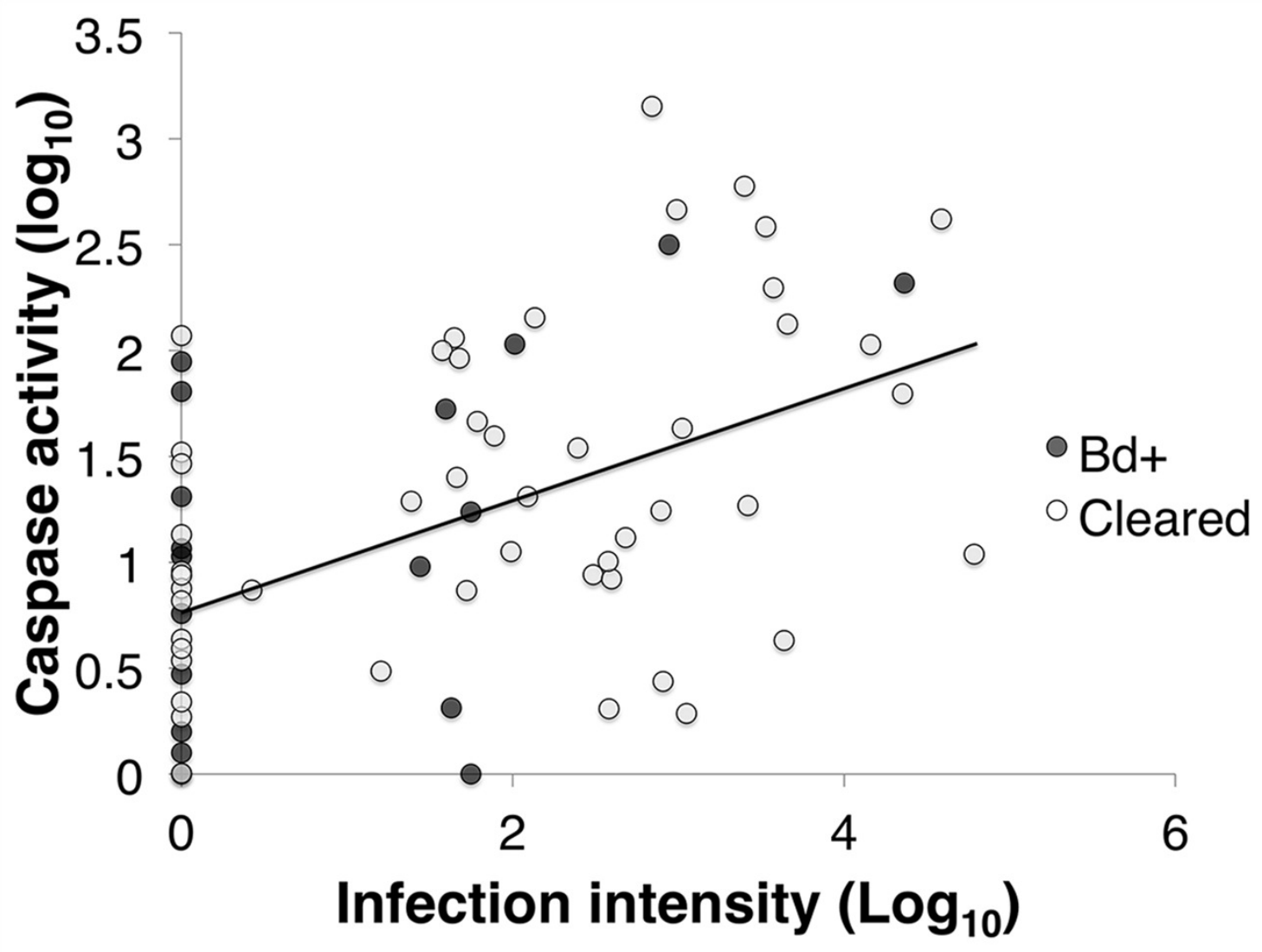

684 
685 Figure 5
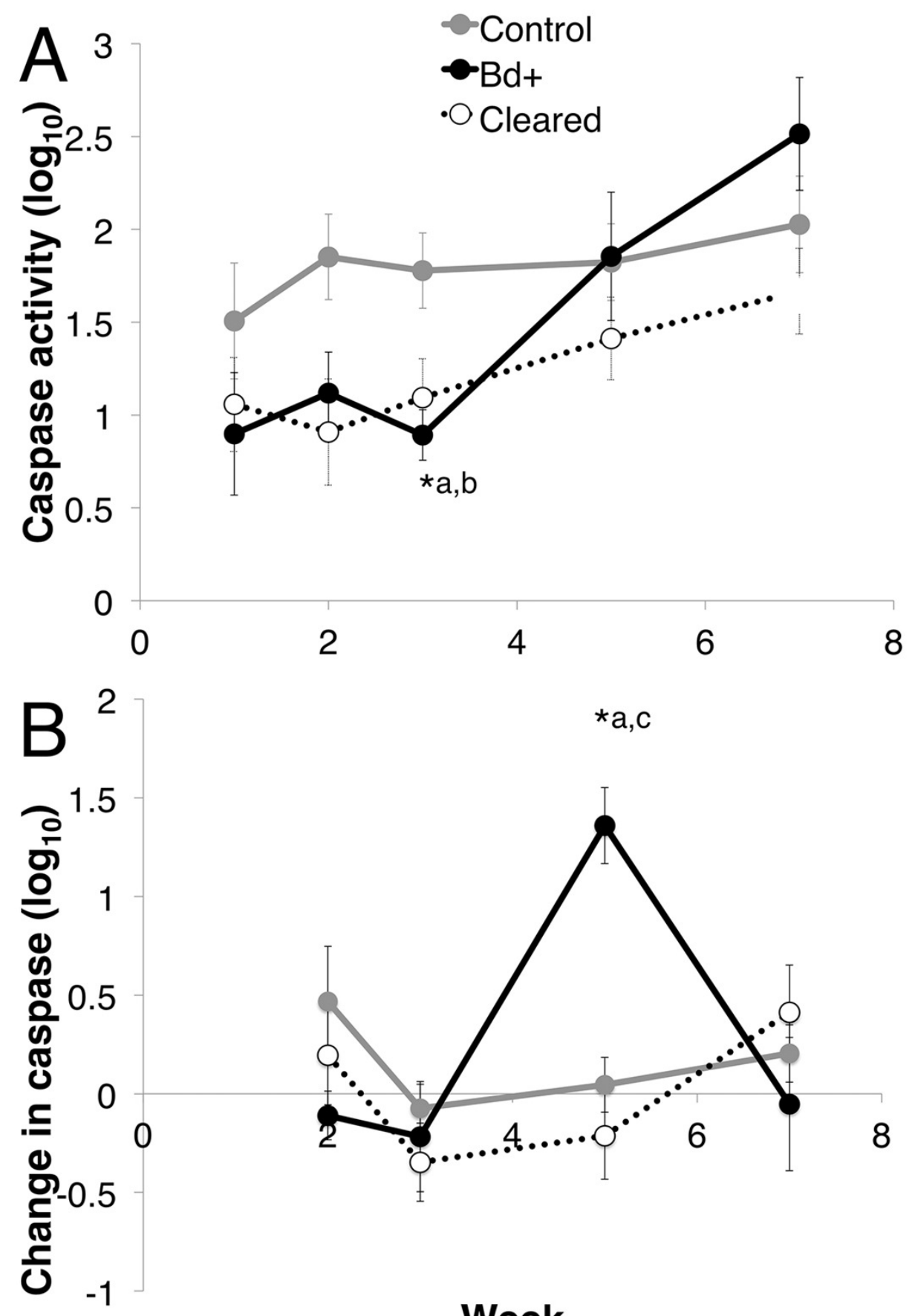

*a,c 
Figure 1

Infection intensity over the course of the experiment in animals that succumbed to chytridiomycosis and those that cleared infection after week 12 in the caspase trial

Infection intensity over the course of the experiment in animals that succumbed to chytridiomycosis $(B d+)(n=4)$ and those that cleared infection (Cleared) $(n=23)$ after week

12 for the Litoria verreauxii alpina in the caspase trial. Infection intensity is $\log _{10}(Z E)$, and error bars indicate standard error.

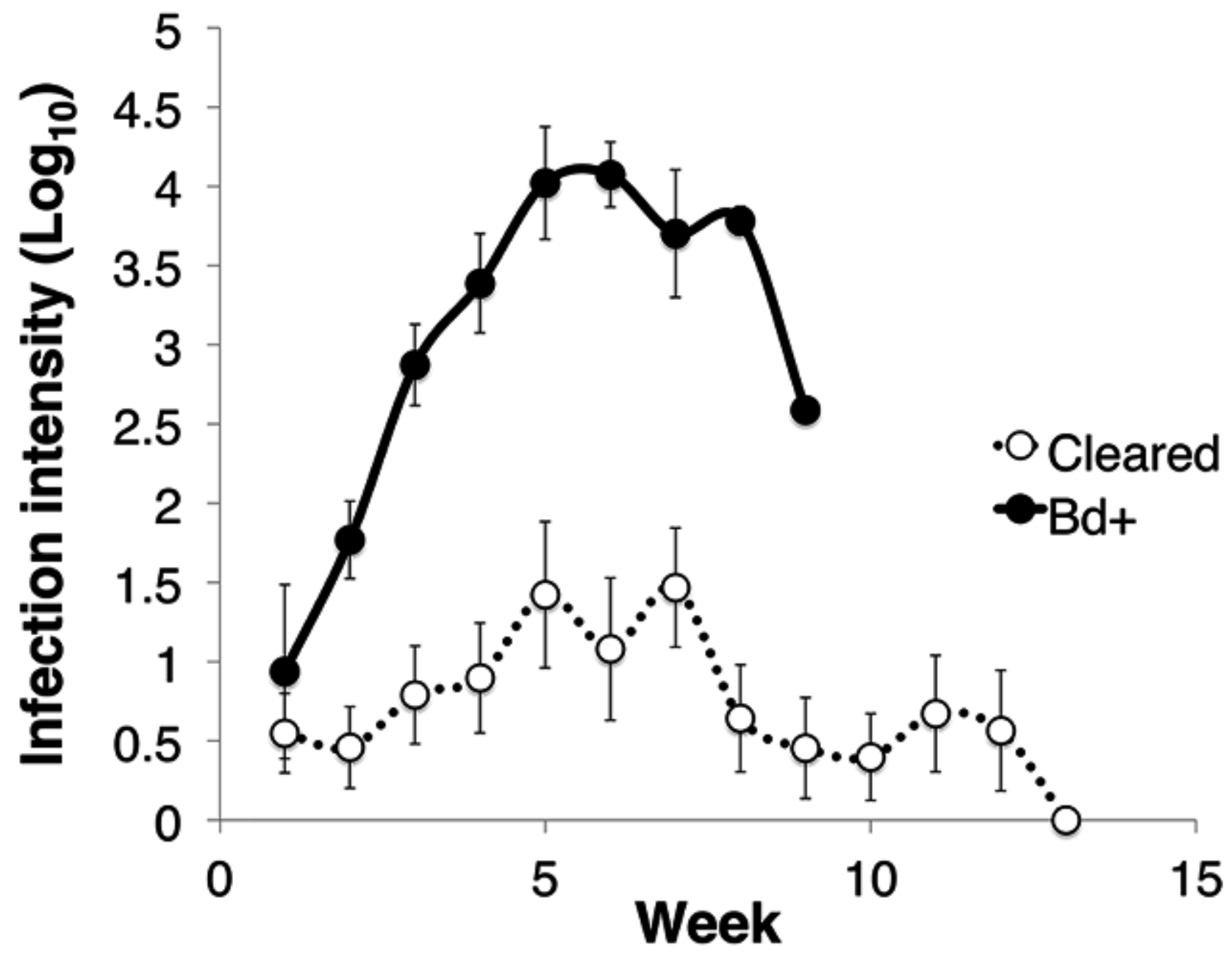




\section{Figure 2}

Terminal transferase-mediated dUTP nick end-labelling (TUNEL) in situ assay of infected and uninfected animals

Terminal transferase-mediated dUTP nick end-labelling (TUNEL) in situ assay of infected and uninfected animals. A) $B d$ - control thigh skin section of Pseudophryne corroboree, and B) $B d+$ thigh skin section of $P$. corroboree stained by in situ TUNEL assay. The blue is DAPI staining indicating nuclei of the cells, and the red is the rhodamine stain, which indicates DNA fragmentation characteristically caused by apoptosis. The yellow arrow indicates the position of the $B d$ cluster seen in panel C. C) $P$. corroboree section of thigh skin stained with H\&E. The $H \& E$ section is serial to panel $B$. There is a cluster of empty $B d$ sporangia (arrow) and a few dark immature sporangia near the skin surface. For all three panels the epidermis is at the top of the photos. Comparing panels $B$ and $C$ shows that the rhodamine stained epidermal cells are concentrated around and below the cluster of $B d$ and where skin damage is visible such as micro-vesicle formation between basal epidermal cells. 400x magnification and the scale bar indicates $0.03 \mathrm{~mm}$. 


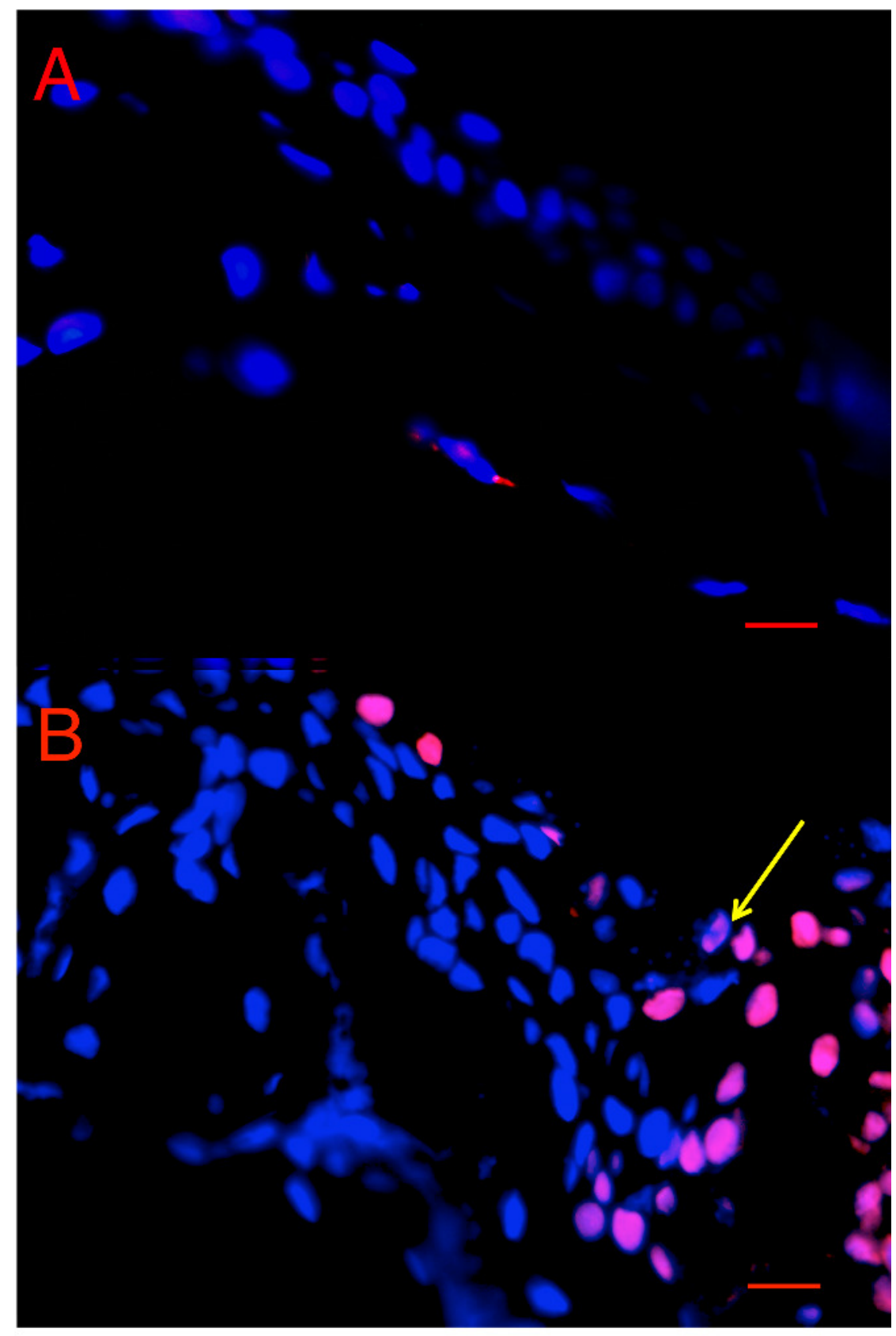

\section{C}

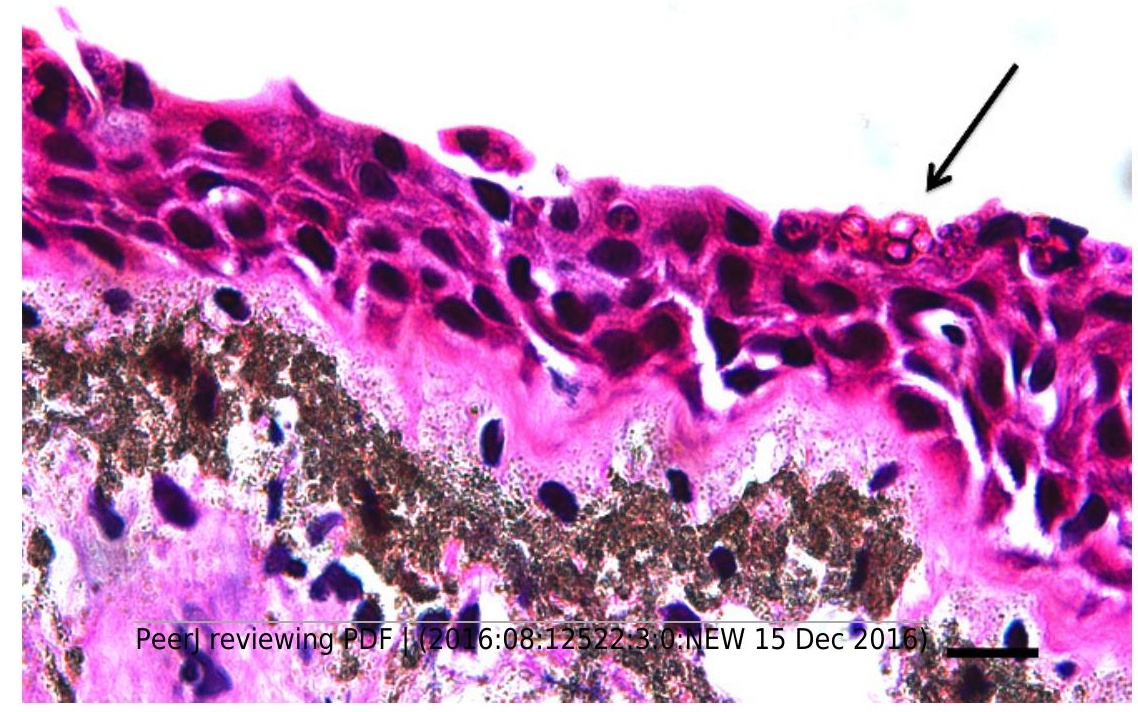


Figure 3

Figure 3 

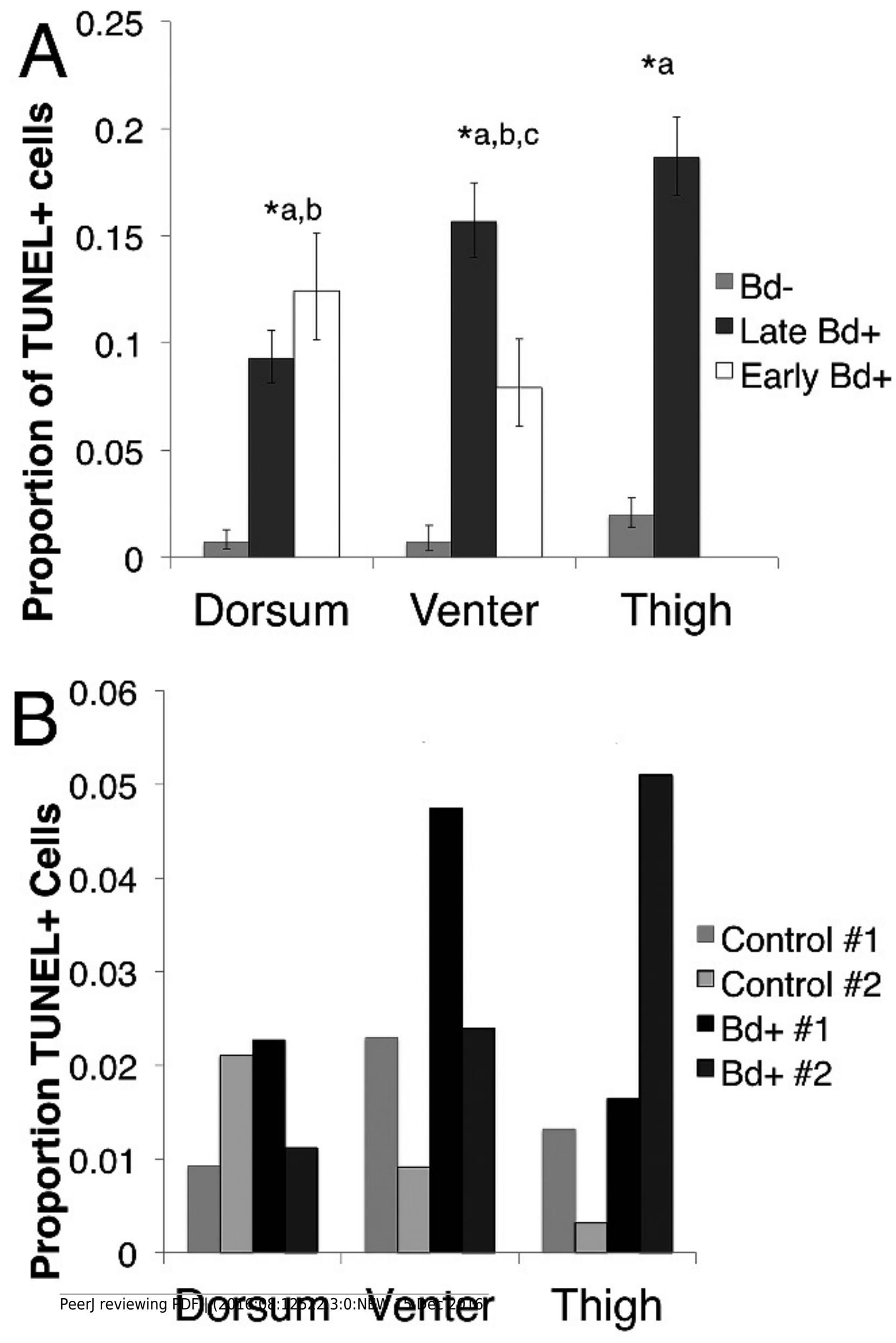


\section{Figure 4}

The proportion of TUNEL positive (TUNEL+) cells per skin type

The proportion of TUNEL positive (TUNEL+) cells per skin type. A) The proportion of TUNEL positive apoptotic cells per skin type in $P$. corroboree with light infection intensity (Early $B d+$, $\mathrm{n}=3$ ), animals that succumbed to disease (Late $B d+, \mathrm{n}=9$ ) and $B d$ - animals $(\mathrm{n}=10)$. Error bars indicate $95 \%$ confidence intervals of a proportion and $*$ indicates a significant increase in apoptotic cell proportions where $\left({ }^{* a}\right)$ indicates a difference between $B d$ - and Late $B d+,\left({ }^{* b}\right)$ indicates a difference between $B d$ - and Early $B d+$, and $(* c)$ indicates a difference between Early $B d+$ and Late $B d+$ skin samples. There was no thigh skin sample taken for the Early $B d+$ group. B) The proportion of TUNEL positive apoptotic cells in $L$. $v$. alpina for $B d$-control animals $(n=2)$ and $B d+$ clinically infected animals $(n=2)$, where each individual is represented as a separate bar. * indicates a difference between the control and $B d+$ animals. 


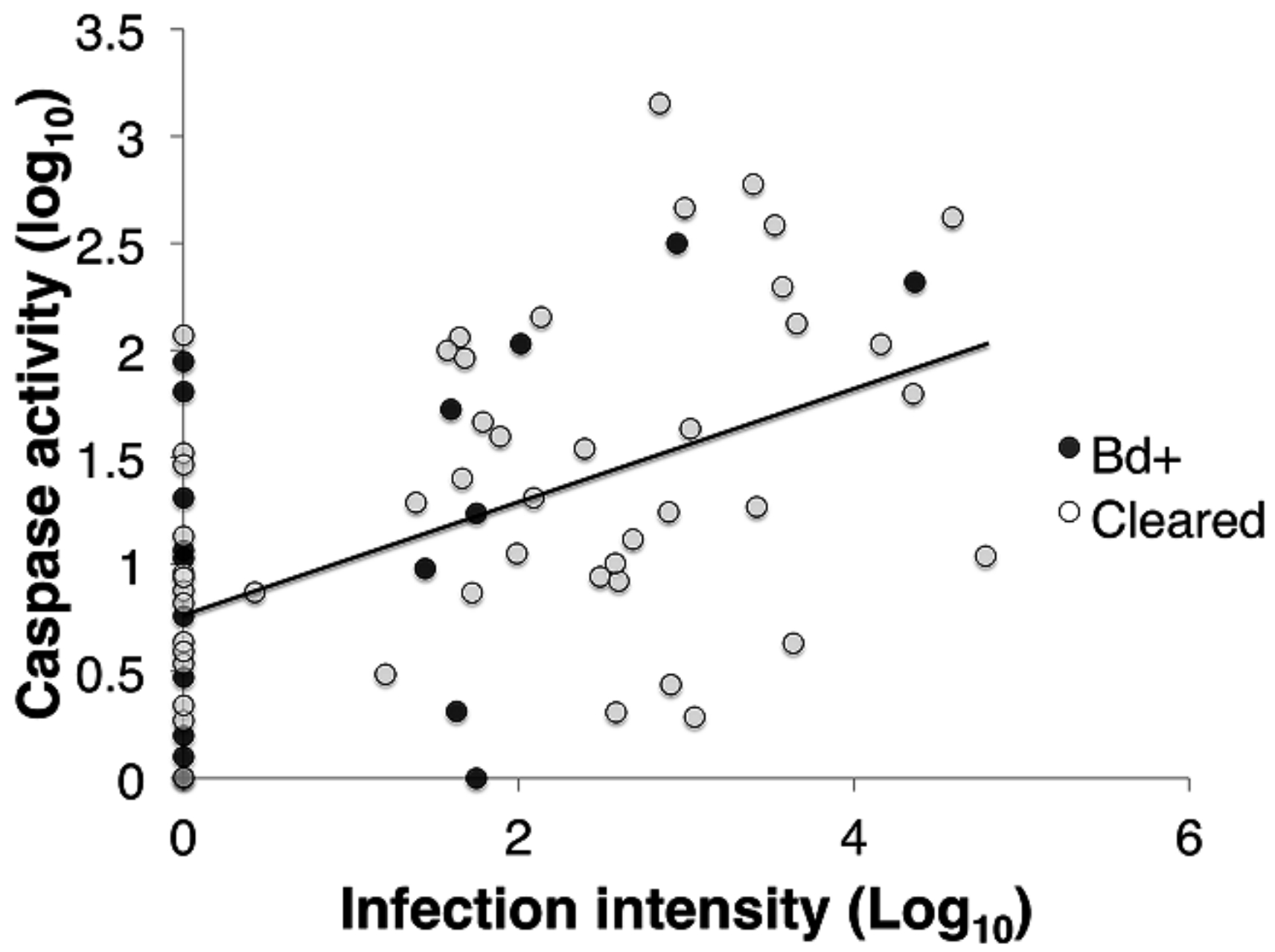




\section{Figure 5}

Caspase 3/7 activity through week 7 for each group of L. v. alpina

Caspase 3/7 activity through week 7 for each group of $L$. v. alpina: $B d+$ that succumbed $(B d+, n=4)$, controls $(n=8)$ and $B d$ inoculated that cleared infection (Cleared, $n=23)$. Caspase activity is defined as the lumiunecence reading controlled for by protein concentration per sample and then log base 10 transformed. A) The caspase activity ( $\log _{10}$ transformed) for each group per week. B) The weekly change in caspase activity $\left(\log _{10}\right.$ transformed) for each group. Error bars indicate standard error. *a indicates the $B d+$ group differed significantly from the control group at that week, *b indicates the cleared group differed from the control group, and *c indicates that the $B d+$ group differed from the Cleared group. 

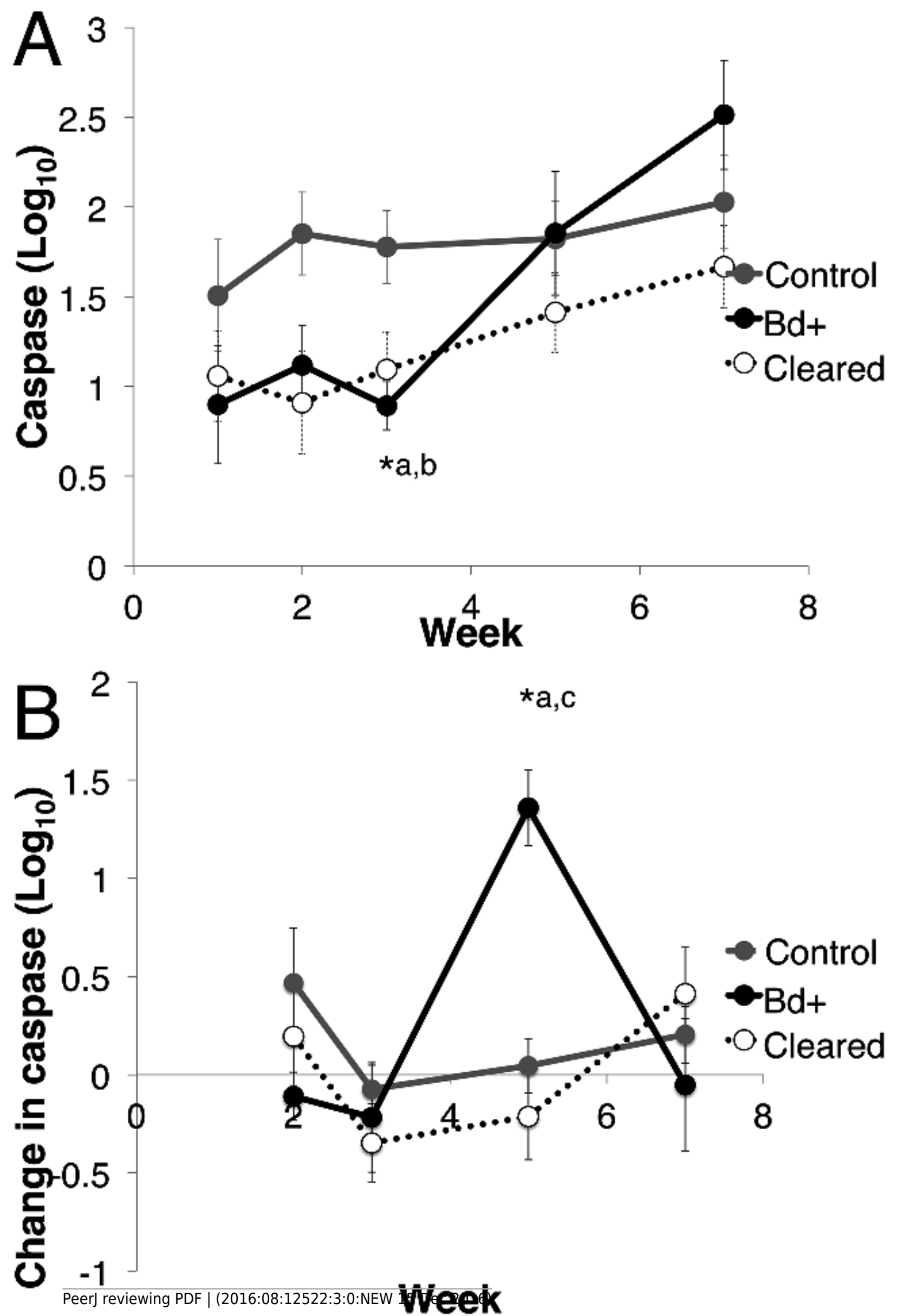


\section{Table $\mathbf{1}$ (on next page)}

Sample size and species for each experiment 
1 Table 1. Sample sizes for all animals inoculated, and the subset of animals used in each assay.

2

\begin{tabular}{|c|c|c|c|c|c|c|c|}
\hline \multirow[b]{2}{*}{ Species } & \multirow[b]{2}{*}{ Assay } & \multicolumn{2}{|c|}{ Total animals } & \multicolumn{4}{|c|}{ Subset Used } \\
\hline & & Inoculated & Control & $B d+$ & Control & $B d+$ Early & $B d$-cleared \\
\hline \multirow[t]{2}{*}{ Litoria $v$. alpina } & TUNEL & 6 & 7 & 2 & 2 & & \\
\hline & Caspase & 27 & 8 & 4 & 8 & & 11 \\
\hline Pseudophryne corroboree & TUNEL & 13 & 6 & 10 & 5 & 3 & \\
\hline
\end{tabular}

